\title{
Is the future of personalized therapy in triple-negative breast cancer based on molecular subtype?
}

\author{
Fanny Le Du ${ }^{1,2}$, Bedrich L. Eckhardt ${ }^{1}$, Bora Lim $^{1,6}$, Jennifer K. Litton ${ }^{1,3,6}$, Stacy \\ Moulder $^{1,6}$, Funda Meric-Bernstam ${ }^{4,6}$, Ana M. Gonzalez-Angulo ${ }^{1,5,6}$, Naoto T. \\ Ueno $^{1,6}$ \\ ${ }^{1}$ Department of Breast Medical Oncology, The University of Texas MD Anderson Cancer Center, Houston, TX, USA \\ ${ }^{2}$ Department of Medical Oncology, Eugène Marquis Cancer Center, Rennes, France \\ ${ }^{3}$ Clinical Cancer Genetics Program, The University of Texas Graduate School of Biomedical Sciences, Houston, TX, USA \\ ${ }^{4}$ Department of Investigational Cancer Therapeutics, The University of Texas MD Anderson Cancer Center, Houston, TX, USA \\ ${ }^{5}$ Department of Systems Biology, The University of Texas MD Anderson Cancer Center, Houston, TX, USA \\ ${ }^{6}$ The University of Texas MD Anderson Women's Cancer Moons Shot Program, Houston, TX, USA \\ Correspondence to: \\ Naoto T. Ueno, e-mail: nueno@mdanderson.org \\ Keywords: triple-negative breast cancer, gene expression profiling, epithelial-mesenchymal transition, immunotherapy, \\ targeted therapy \\ Received: February 17, 2015 \\ Accepted: April 24, 2015 \\ Published: May 07, 2015
}

\section{ABSTRACT}

\begin{abstract}
Significant research has been conducted to better understand the extensive, heterogeneous molecular features of triple-negative breast cancer (TNBC). We reviewed published TNBC molecular classifications to identify major groupings that have potential for clinical trial development. With the ultimate aim to streamline translational medicine, we linked these categories of TNBC according to their geneexpression signatures, biological function, and clinical outcome. To this end, we define five potential clinically actionable groupings of TNBC: 1) basal-like TNBC with DNA-repair deficiency or growth factor pathways; 2) mesenchymal-like TNBC with epithelial-to-mesenchymal transition and cancer stem cell features; 3) immuneassociated TNBC; 4) luminal/apocrine TNBC with androgen-receptor overexpression; and 5) HER2-enriched TNBC. For each defined subtype, we highlight the major biological pathways and discuss potential targeted therapies in TNBC that might abrogate disease progression. However, many of these potential targets need clinical validation by clinical trials. We have yet to know how we can enrich the targets by molecular classifications.
\end{abstract}

\section{INTRODUCTION}

Triple-negative breast cancer (TNBC), which accounts for $10-20 \%$ of all breast cancers, does not express estrogen receptors (ERs) or progesterone receptors (PRs) and lacks human epidermal growth factor receptor-2 (HER2) amplification. Patients diagnosed with TNBC have a higher risk of disease relapse within 5 years than patients treated for other breast cancer subtypes [1]. Thus, identification and evaluation of new biomarkers and therapeutic agents is a high priority. Because TNBC is a heterogeneous disease, many pathological and immunohistochemical subclassification have been proposed in the past decade to define more homogeneous subtypes. More recent advances have focused on disease stratification through the use of genome-wide approaches. Such "molecular portraits" of breast cancer are envisioned to provide a rationale for breast cancer prognosis and prediction to therapy. In this article, we sought to understand the classifications of TNBC based on similar gene-expression signatures and biological functions and their clinical relevancy.

Search strategy and selection criteria

We conducted a Medline search up to December 2014 with use of the terms "triple negative" and "breast neoplasm" and/or search strings connected to the topics of interest—e.g., "classification", "gene expression profiling", 
"drug therapy" - without restrictions to date. Furthermore, references cited in the retrieved articles were screened for additional articles. Moreover, proceedings from the American Society of Clinical Oncology conference, the European Society of Medical Oncology conference, and the San Antonio Breast Cancer Symposium were researched in the abstract book for relevant presentations. We excluded publications not written in English, with impact factor $<3$, with less than 10 citations (except for papers published less than 12 months ago). We also tried to select only one paper per team (except for gene expression profiling papers). Then, based on abstract concordance to our subject, we reviewed 315 papers. Ongoing clinical trials were searched using the http://clinicaltrials.gov site and referenced by their National Clinical Trial (NCT) number.

We initially screened for overlapping classifications of TNBC in whole-genome gene-expression profiling (GEP) papers and identified four majors classifications: the claudinlow [2], the intrinsic-PAM50 [3], and the molecular subsets described by Burstein et al [4]. and Lehmann et al [5]. We also searched for validated gene-expression signatures and markers of specific biological functions in TNBC populations. We cross-referenced the obtained information to identify clinically actionable TNBC groupings with similar gene-expression signatures, biological functions, and clinical outcomes. Although, recent papers highlighted the similarities and discrepancies of intrinsic PAM50 subtyping and Lehmann's seven subtypes [6-8], our incomplete knowledge of TNBC - validated gene signature, biomarkers or targeted therapies - precludes our ability to provide a consensus on clinically achievable TNBC subgrouping. Due to the lack of consensus on comprehensive treatment strategies for TNBC, we tried to re-organize the classification into theranostic subgroups with clinical relevance: detectable targets/pathway aberrations and available/potential targeted therapy.

\section{TNBC molecular subtypes with future clinical relevance and potential therapeutics}

We here provide five molecular groupings of TNBC that may have the greatest potential for clinical trial development using major previously published molecular classifications (PAM50 subtyping, claudinlow, Burstein's four subtypes and Lehmann's seven subtypes): 1) basal-like TNBC (BL-TNBC), characterized predominantly by DNA-repair deficiency but also growth factor pathway expression; 2) mesenchymal-like TNBC (ML-TNBC), with epithelial to mesenchymal transition (EMT) and cancer stem cell (CSC) features; 3) immuneassociated TNBC (I-TNBC); 4) luminal/apocrine TNBC (LA-TNBC), with androgen receptor (AR) overexpression; and 5) HER2-enriched TNBC (HER2e-TNBC) (Figure 1).

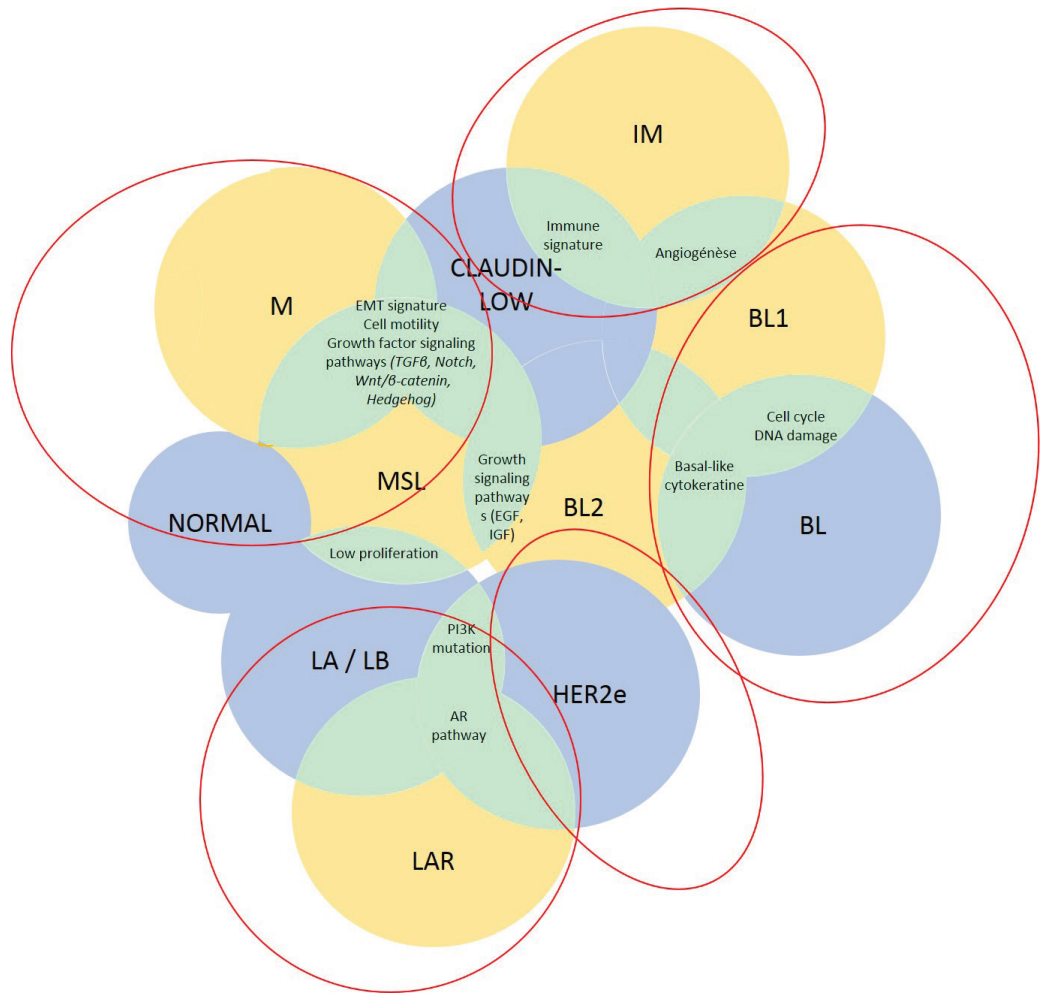

Figure 1: TNBC classifications. Lehmann's (yellow), PAM50/claudin-low (blue) classifications and their potent overlaps (green) are shown in this figure.

Abbreviations: AR, androgen receptor; BL, basal-like; EGF, epidermal growth factor; HER2, human epidermal growth factor receptor 2; IGF, insulin growth factor; IM, immunomodulary; LAR, luminal androgen receptor; M, mesenchymal; MSL mesenchymal stem-like; TGF $\beta$, transforming growth factor $\beta$. 
Next, we highlighted the key molecular pathways that are represented in these groups, with a specific interest towards identifying potential therapies that could be utilized to target each disease.

\section{Basal-like TNBC}

The predominant molecular grouping of TNBC is BL-TNBC, which makes up approximately 25\% to $80 \%$ of TNBC cases, depending on the definition used. Published definitions have been based on either immunohistochemical (IHC) characterization (CK5/6+; epidermal growth factor receptor (EGFR)+; ER-; HER2-) or GEP, without definitive consensus [9]. Although a matter of debate, several common characteristics have been observed in both descriptions of BL-TNBC, including high proliferative capacity and overexpression of BL cytokeratin genes (keratin-5 and -14) $[5,10]$.
According to Lehmann et al., BL-TNBC can be separated into two subgroups, basal-like 1 (BL1) and basal-like 2 (BL2) [5]. Profiling studies indicate that the BL1 subgroup is heavily enriched in the cell cyclerelated genes and in DNA-damage repair pathways, which may be expected in highly proliferative tumors [5]. $25 \%$ of sporadic breast cancers harbor a deficiency in the DNA-repair, mainly in homologous recombination (HR) when double stranded DNA breakage occurs - similar to the genetic deficiency of $B R C A 1$ or $B R C A 2$ mutation carriers-leading to a subtype referred to as "BRCAness" $[11,12]$. BL2 subgroup on the other hand is uniquely enriched in growth factor signaling pathways like EGF, MET pathway as well as IGF1R pathway.

BL-TNBC has one of the highest pathologic complete response ( $\mathrm{pCR}$ ) rates following chemotherapy [13]. As a group, targeting DNA-repair deficiency appears to be a promising treatment for BL-TNBC with BRCAness characteristics or BRCA-mutations (Table 1, Figure 2, and

Table 1: Potential therapeutic approaches based on TNBC classification

\begin{tabular}{|c|c|c|c|c|}
\hline $\begin{array}{l}\text { Potential Therapeutic } \\
\text { Subgroups }\end{array}$ & Drug class & $\begin{array}{l}\text { Drugs (Given alone or with } \\
\text { standard CHT) }\end{array}$ & $\begin{array}{l}\text { Ongoing Trials } \\
\text { (Phase) }\end{array}$ & $\begin{array}{l}\text { Published Results of } \\
\text { Clinical trials }\end{array}$ \\
\hline \multicolumn{5}{|l|}{ Basal } \\
\hline \multirow[t]{4}{*}{ DNA-repair deficiency } & \multirow[t]{2}{*}{ Platinum } & Cisplatin & $\begin{array}{l}\text { NCT01672671(2) } \\
\text { NCT01982448(2)\# }\end{array}$ & $\begin{array}{l}50 \% \text { of good pathologic } \\
\text { response (Miller-Payne } \\
3 \text { to5) [14]. }\end{array}$ \\
\hline & & Carboplatin & $\begin{array}{l}\text { NCT01752686(3) } \\
\text { NCT00532727(3) }\end{array}$ & $\begin{array}{l}48 \% \text { of pCR when } \\
\text { associated with } \\
\text { standard CHT [15]. } \\
68 \% \text { and } 33 \% \text { of ORR } \\
\text { for carboplatin and } \\
\text { docetaxel for BRCA } \\
\text { mutant patients [19]. }\end{array}$ \\
\hline & PARP inhibitors & Olaparib & NCT00707707(1) & $\begin{array}{l}37 \% \text { of partial } \\
\text { response when } \\
\text { associated with weekly } \\
\text { paclitaxel [99]. }\end{array}$ \\
\hline & & Veliparib* & NCT02032277(3) & \\
\hline \multirow[t]{2}{*}{ Cell cycle } & CDK inhibitors & Dinaciclib & NCT01624441(1) & \\
\hline & & P276-00* & NCT01333137(1) & \\
\hline \multicolumn{5}{|l|}{ Mesenchymal } \\
\hline Notch & GSI & RO4929097 & NCT01151449(2) & \\
\hline Hedgehog & SMO inhibitors & Erismodegib & NCT01757327(2) & \\
\hline c-MET & c-MET-TKI & Tivantinib & NCT01542996(2) & $\begin{array}{l}\text { Inactive as } \\
\text { monotherapy [100]. }\end{array}$ \\
\hline
\end{tabular}

(Continued) 


\begin{tabular}{|c|c|c|c|c|}
\hline $\begin{array}{l}\text { Potential Therapeutic } \\
\text { Subgroups }\end{array}$ & Drug class & $\begin{array}{l}\text { Drugs (Given alone or with } \\
\text { standard CHT) }\end{array}$ & $\begin{array}{l}\text { Ongoing Trials } \\
\text { (Phase) }\end{array}$ & $\begin{array}{l}\text { Published Results of } \\
\text { Clinical trials }\end{array}$ \\
\hline & MET-mAb & Onartuzumab & NCT01186991(2) & $\begin{array}{l}\text { No PFS improvement } \\
\text { when added to CHT } \\
\text { and bevacizumab [38]. }\end{array}$ \\
\hline $\begin{array}{l}\text { Targeted therapies } \\
\text { combination }\end{array}$ & $\begin{array}{l}\text { GSI - SMO } \\
\text { inhibitors }\end{array}$ & RO4929097 - Vismodegib & NCT01071564(1) & \\
\hline \multicolumn{5}{|l|}{ Immune-associated } \\
\hline Tumor vaccine & MUC-1 vaccine & MUC1 peptide vaccine & NCT00986609(0) & \\
\hline $\begin{array}{l}\text { Immune checkpoint } \\
\text { blockade }\end{array}$ & Anti-PD-L1 & $\begin{array}{l}\text { Pembrolizumab } \\
\text { MPDL3280A }\end{array}$ & $\begin{array}{l}\text { NCT01848834(1) } \\
\text { NCT01375842(1) }\end{array}$ & $\begin{array}{l}\text { ORR of } 16.1 \% \text { in } \\
\text { advanced TNBC [101]. } \\
\text { ORR of } 33 \% \text { in } \\
\text { metastatic TNBC [102]. }\end{array}$ \\
\hline CSF-1R & CSF-1R inhibitors & PLX3397 & NCT01596751(2) & \\
\hline \multicolumn{5}{|l|}{ Luminal/Apocrine } \\
\hline \multirow[t]{3}{*}{ AR } & $\begin{array}{l}\text { Androgen } \\
\text { biosynthesis } \\
\text { inhibitor }\end{array}$ & Abiraterone acetate & NCT01842321(2)\# & \\
\hline & AR inhibitor & Enzalutamide* & NCT01889238(2)\# & $\begin{array}{l}42 \% \text { CBR after } \\
16 \text { weeks }[60]\end{array}$ \\
\hline & & Bicalutamide & $\begin{array}{l}\text { NCT02353988(2)\# } \\
\text { NCT02348281(2)\# }\end{array}$ & \\
\hline HDAC & $\begin{array}{l}\text { HDAC inhibitor - } \\
\text { Endocrine therapy }\end{array}$ & $\begin{array}{l}\text { Entinostat - Anastrozole } \\
\text { LHB589 - Tamoxifen }\end{array}$ & $\begin{array}{l}\text { NCT01234532(2) } \\
\text { NCT01194908(2) }\end{array}$ & \\
\hline
\end{tabular}

Overlapping potential targets

\begin{tabular}{llll}
\hline EGFR & EGFR mAb & Cetuximab* & NCT00463788(2) \\
& & & \\
& & Panitumumab* & NCT00894504(2) \\
& EGFR-TKI [69] & Gefitinib & NCT01732276(2)\# \\
PI3K/AKT/mTOR & Pan PI3K inhibitor & Buparlisib & NCT00491816(2) \\
& & & NCT01629615(2) \\
& & Pictilisib* & NCT01790932(2) \\
MAPK & MTOR inhibitor & Everolimus* & NCT01918306(2)\# \\
& MEK inhibitor & Trametinib & NCT01939418(2) \\
& & NCT01931163(2) & NCT01467310(B)
\end{tabular}

ORR and PFS doubled with cetuximab and cisplatin [70].

80\% ORR when added to CHT [71].

NCT01732276(2)\#

NCT00491816(2)

NCT01629615(2)

(1790932(2)

NCT01939418(2)

NCT01931163(2)

NCT01467310(B)

Adjuvant setting: No improvement in DFS [85].

$\begin{array}{lll}\text { VEGF } & \text { VEGF mAb NCTacizumab* } & \text { NC1898117(2) }\end{array}$

Metastatic setting: $35 \%$ reduced risk of relapse and a $19 \%$ RR without improved OS [86].

(Continued) 
Potential Therapeutic Drug class Subgroups

\begin{tabular}{|c|c|c|c|c|}
\hline & VEGFR-TKI & Sorafenib* & NCT01194869(2) & \\
\hline & & Sunitinib* & NCT00887575(2) & $\begin{array}{l}\text { Monotherapy showed } \\
\text { no efficacy compared } \\
\text { to SOC in previously } \\
\text { treated advanced } \\
\text { TNBC [103]. }\end{array}$ \\
\hline & & Tivozanib & NCT01745367(2) & \\
\hline & & Apatinib & NCT01176669(2) & \\
\hline \multirow{3}{*}{$\begin{array}{l}\text { Targeted therapy } \\
\text { combinations }\end{array}$} & $\begin{array}{l}\text { VEGFR and } \\
\text { c-MET-TKI }\end{array}$ & Cabozantinib & NCT01738438(2)\# & \\
\hline & $\begin{array}{l}\text { MEK inhibitor - } \\
\text { AKT inhibitor }\end{array}$ & Trametinib - GSK2141795 & NCT01964924(2) & \\
\hline & $\begin{array}{l}\text { VEGF inhibitor - } \\
\text { c-MET inhibitor }\end{array}$ & Bevacizumab - Onartuzumab & NCT01186991(2) & \\
\hline
\end{tabular}

Based on our Classification, drugs specially investigated on a cohort of TNBC patients are listed in this table. These drugs are presented according to the pathway they target and thus illustrate our TNBC grouping.

* Ongoing trials evaluating targeted therapy in combination with platinum-based regimens.

\#Trials enrolling TNBC patients.

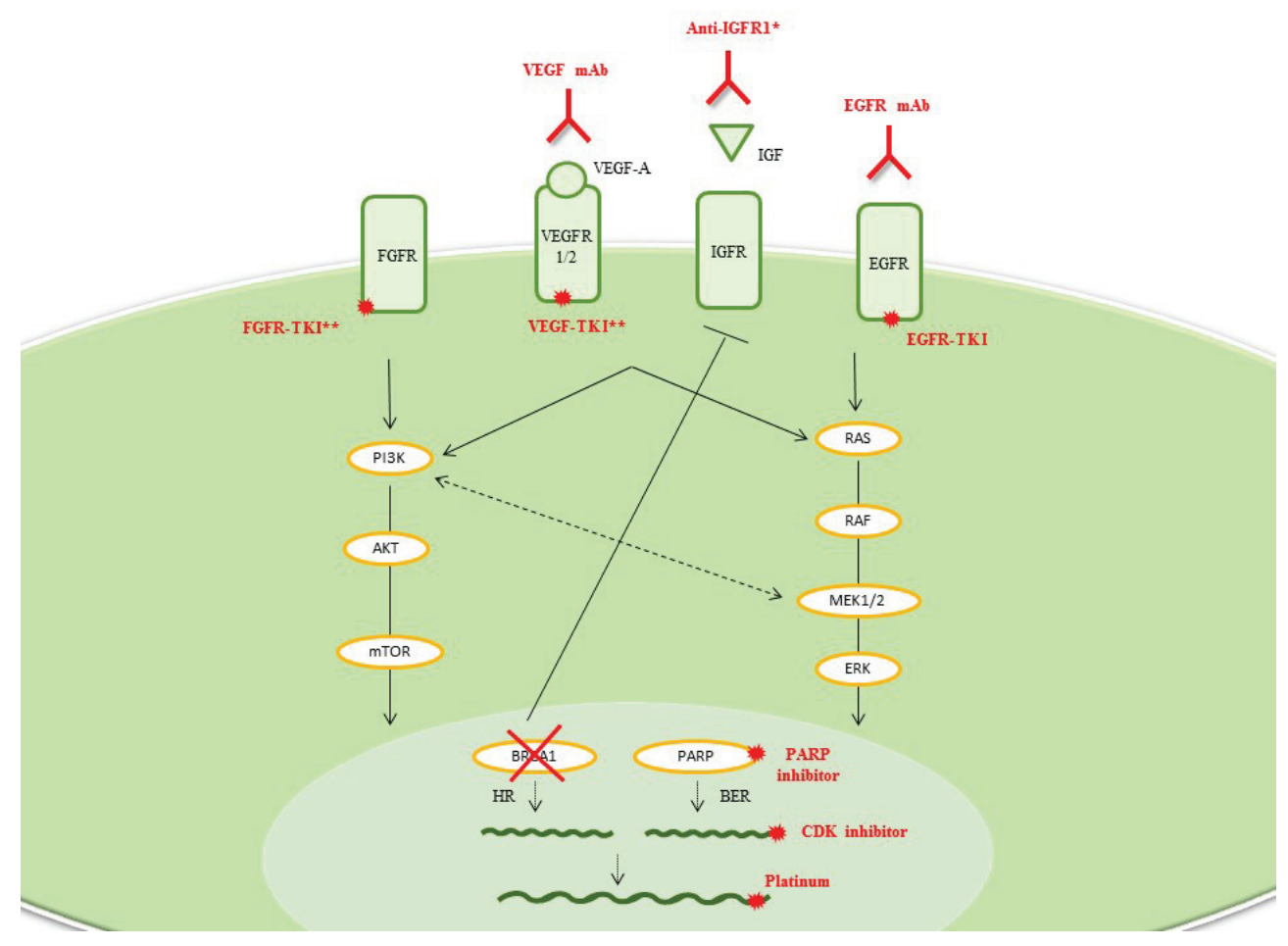

Figure 2: Basal-like TNBC. Drug classes previously evaluated or currently being investigated in breast cancer clinical trials are shown. *More than 100 studies of anti-IGFR1 therapy (anti-receptor Abs, anti-ligand Abs, receptor-TKIs, and metformin) have been conducted. **Many combination drugs are currently being investigated: EGFR and HER2-TKIs (e.g., lapatinib and BIBW2992), c-MET and VEGFRTKIs (e.g., cabozantinib) or FGFR and VEGFR-TKIs (e.g., lucitanib, dovitinib, BIBF1120).

Abbreviations: BER, base-excision repair; CDK, cyclin-dependent kinase; EGFR, epidermal growth factor receptor; FGFR, fibroblast growth factor receptor; IGFR, insulin growth factor receptor; HR, homologous recombination; mAb, monoclonal antibody; TKI, tyrosinekinase inhibitor; VEGFR, vascular endothelial growth factor receptor. 
Supplementary Table 1). However, when one takes a close look, there was a significantly large difference in pCR rate between BL1 (51\%) and BL2 (0\%) subgroups, raising serious concerns about therapeutic applications whether to consider BL1 and BL2 as the same entity [8]. However, this requires prospective validation in large cohort of patients with TNBC. However, we can speculate that BL2 tumors display a gene signature that suggests activation of receptor tyrosine kinase pathways, suggesting that this subgroup may need to be grouped together with other subgroups harboring enriched growth factor/receptor tyrosine kinase pathways like mesenchymal like subgroup (see ML-TNBC) [5].

\section{Platinum-based chemotherapy}

Given the defective DNA-repair system as described above, the targeting DNA-repair deficiency appears to be a promising treatment for BL-TNBC with BRCAness characteristics or BRCA-mutations (more likely BL1: Table 1, Figure 2, and Supplementary Table 1). Chemotherapies based on the DNA crosslinking agent platinum could be effective for sporadic or germline DNA-repair-deficient breast cancers. Indeed, good response rates (RRs) to such agents have been associated with low BRCA1-mRNA expression and BRCA1 methylation [14, 15]. Platinum-based chemotherapy appears to significantly increase the $\mathrm{pCR}$ rate in TNBC patients $[15,16]$. However, these results seem to be driven by patients with a family history of cancer and/or BRCA-positivity, who have a higher pCR rate $(49 \%-64 \%)$ than the rest of the population $(40 \%)$ [17]. In the metastatic setting, patients harboring BRCA mutations responded better to carboplatin than docetaxel. If BRCAness signature (as estimated by HR deficiency assay) appeared as a potent biomarkers of platinum sensitivity in TBCRC009 trial; it was not predictive of platinum response in the phase III TNT trial $[18,19]$. These data support the use of platinum-based regimens for BRCA-mutant TNBC. As a result, carboplatin has been incorporated into combinatorial treatment in TNBC patients; however more careful selection of patients using BRCAness testing should be warranted.

\section{Poly-ADP ribose polymerase (PARP) inhibitor}

Alterations in DNA-damage response and repair mechanisms can lead to genomic instability and carcinogenesis, but may also offer a target for treatment in highly proliferative tumors such as BL-TNBC. Indeed, HR dysfunction has been shown to sensitize breast cancer cells to PARP inhibition, resulting in cell cycle arrest and apoptosis [20]. Preclinical data demonstrated that PARP inhibitor olaparib has antitumor activity in BRCA-mutant cell lines [21], this was later confirmed in a phase II trial [22]. The phase III study of iniparib did not meet this goal, with the negative result attested to iniparib's poor inhibitory action against PARP $[23,24]$. New, highly potent PARP inhibitors, such as BMN-673 are in early stage development and the results of their clinical utility eagerly awaited [25]. Combination treatment appear promising based on preliminary results of the I-SPY2 trial which reported a doubled pCR rate when veliparib and carboplatin were added to standard neoadjuvant chemotherapy regimens [26]. Another interesting observation is that CDK inhibitors provided a therapeutic target for PARP inhibitors in BRCA-competent cell lines by increasing DNA damage [27]. Therefore, smart combination strategy may create a novel susceptibility to DNA repair targeting therapeutics in non BL1 TNBC, and can be used as one strategy to induce pathologic response to the chemotherapy.

\section{Mesenchymal-like TNBC}

Mesenchymal, mesenchymal stem like, claudinlow are generally indicating the subgroups of TNBC that harbor mesenchymal like features-represented by enriched genes involved in EMT and the biological regulation of CSCs [2, 5]. Interestingly, most mesenchymal stem-like (MSL) samples are usually classified as normal-like, whereas most mesenchymal (M) tumors are classified as Basal-like when tested by PAM50 (when the "claudin-low" subgroup is not considered) [7]. It could actually suggest that the MSL group of tumors is actually composed of tumors highly contaminated by normal breast tissue. These discrepancies were also noticed in the smaller cohort of Burstein et al.: MSL overlapped with a mesenchymal subgroup whereas M tumors were mostly Basal-Like Immune-suppressed (BLIS) [4].

During EMT, epithelial breast cancer cells acquire the expression of mesenchymal markers while losing the expression of epithelial-related genes involved in the maintenance of cellular junctions. While comparing EMT markers, it was recognized that elevated vimentin and decreased E-cadherin protein expression in TNBC cells could stratify a mesenchymal-TNBC subgroup (Supplementary Figure 1). From the signaling pathway perspective, the activation of EGFR, which is frequently overexpressed in TNBC, has been implicated in EMT, as have other tyrosine-kinase receptors (e.g., c-MET, fibroblast growth factor, insulin growth factor [IGF], platelet-derived growth factor) $[28,29]$. Other pathways, including the transforming growth factor $\beta$ (TGF $\beta$ ), Notch, and $\mathrm{Wnt} / \beta$-catenin signaling pathways [29], are also involved in EMT, and many of these are heavily enriched in ML-subtype [5]. Mesenchymal cells also harbor CSClike features, the hallmarks of metastatic potential. In an unsupervised analysis of a collection of breast cancer cell lines, Neve et al. described a cluster of TNBC cells that exhibited a CSC-like expression profile [30]. Moreover, the induction of a CSC profile or the expression of mesenchymal markers in breast cancer cells have been correlated with chemotherapy resistance [31]. CSC-like 
features, consistent with EMT phenotype, are known to be driven by many well-known signaling pathways such as the MAPK and Wnt pathways, which suggest that inhibitors of these pathways should be utilized in conjunction with standard chemotherapy. Many promising EMT-targeted and CSC-targeted treatments are under investigation in early stage clinical trials (Table 1, Figure 3 and Supplementary Table 1).

\section{CSC regulators}

Activation of $\mathrm{Wnt} / \beta$-catenin signaling correlates with the expression of CD44+/CD24- [32]. Despite the inherent difficulties in developing novel Wnt inhibitors, many drugs already approved by the U.S. Food and Drug Administration inhibit Wnt pathways, including vitamin D3, non-steroidal anti-inflammatory drugs and some antibiotics (e.g., salinomycin) [33]. The Notch signaling pathway also has a crucial role in maintaining breast CSCs, and thus may provide a therapeutic avenue in ML-TNBC. To date, two kinds of Notch inhibitors have been developed for oncological purposes: $\gamma$-secretase inhibitors (GSIs) and delta-like ligand 4 monoclonal antibodies (mAbs). In preclinical studies, GSIs have been found to sensitize chemoresistant cell populations, including CSC-like tumor cells [34]. Importantly, functional study suggested that PEST domain mutations of Notch receptors are frequent in TNBC and active Notch pathway conferring GSI sensitivity [35]. Given that Hedgehog ligand, GLI expression and SMO are also up regulated in $\mathrm{TNBC}$, there is a potential opportunity to therapeutically target this pathway; however, no clinical trials have been designed specifically for ML-TNBC.

\section{c-MET targeted therapy}

Targeting this pathway in ML-TNBC could also be successful since c-MET signaling can control EMT and CSC phenotypes [29]. Moreover, stromal secretion of hepatocyte growth factor was recently demonstrated

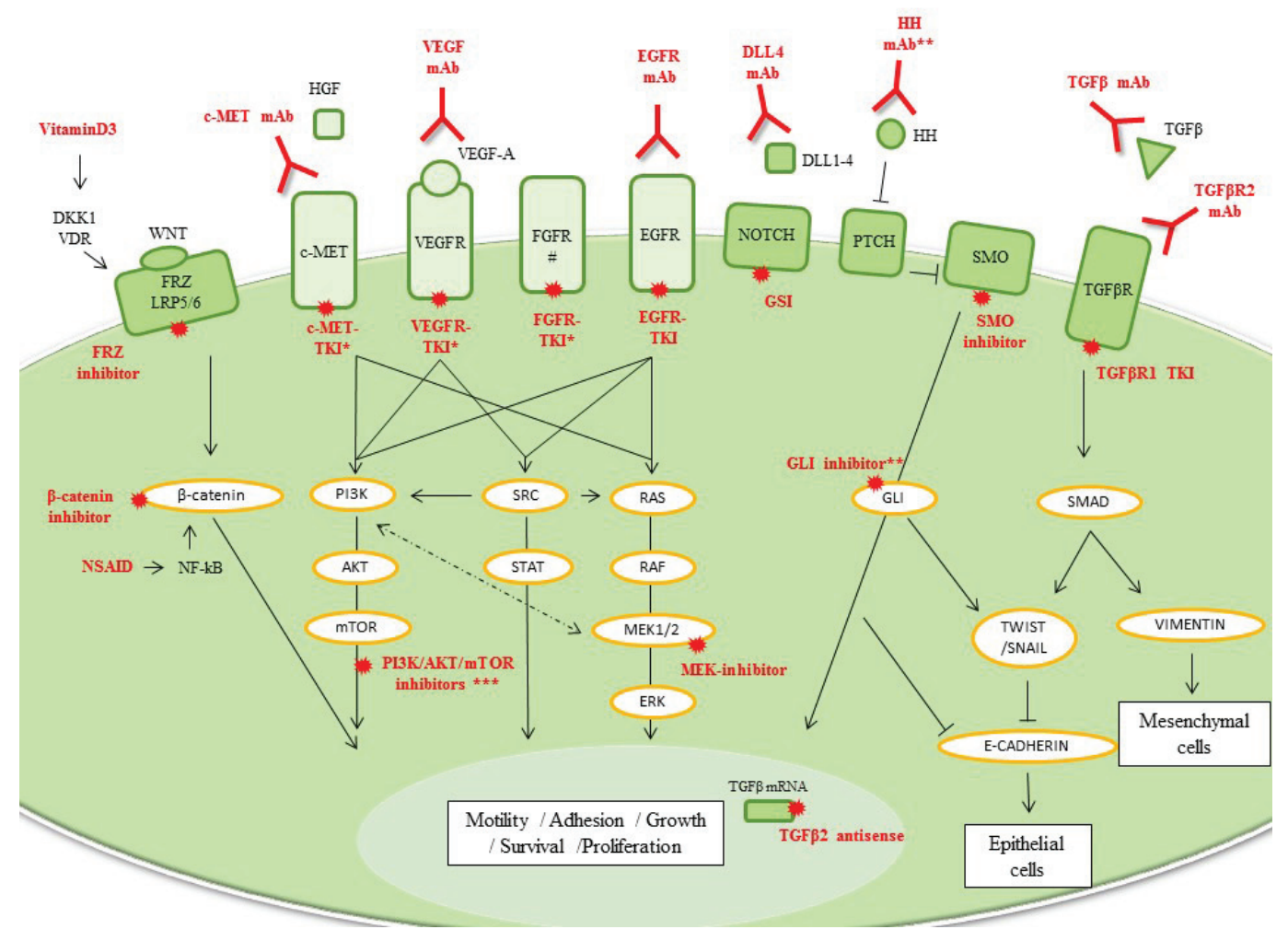

Figure 3: Mesenchymal TNBC. Drug classes previously evaluated or currently being investigated in breast cancer clinical trials are shown. *Many combination drugs are currently being investigated: EGFR and HER2-TKIs; c-MET and VEGFR-TKIs or FGFR and VEGFR-TKIs. **Not yet in clinical trials. ***PI3K/AKT/mTOR inhibitors are detailed in luminal/apocrine-TNBC part (Figure 4). \# PDGFR and IGFR are also overexpressed in ML-TNBC and are targetable. However, current therapies targeting PDGFR have a large overlap with those that target VEGF. Imatinib, an anti-PDGF agent, had potential immunosuppressive effects and no antitumor activity in metastatic breast cancer overexpressing PDGF $\beta$.

Abbreviations: DKK1, Dickkopf-homolog-1; DLL, delta-like ligand; EGFR, epidermal growth factor receptor; FGFR, fibroblast growth factor receptor; FRZ, Frizzle receptor; GSI, $\gamma$-secretase inhibitor; HGF, hepatocyte growth factor; HH, Hedgehog ligand; mAb, monoclonal antibody; NF- $\mathrm{BB}$, nuclear factor $\kappa$-beta; NSAID, non-steroidal anti-inflammatory drug; PTCH, patched receptor; SMO, smoothened; TGF $\beta$, transforming growth factor $\beta$; TKI, tyrosine-kinase inhibitor; VDR, vitamin D receptor; VEGFR, vascular endothelial growth factor receptor. 
to activate the c-MET pathway and leads to resistance to EGFR-TKIs in breast cancers, an effect already wellknown in non-small cell lung cancer [36]. Appropriately, co-inhibition of EGFR and c-MET suppressed tumor growth in preclinical models [37]. However, initial results with c-MET inhibitors were disappointing, with no improvement of progression-free survival when onartuzumab was given with paclitaxel/ bevacizumabbased regimens in unselected metastatic TNBC patients [38]. However, with better understanding of pathway and possible expanded target group including BL2 TNBCs showing enriched in genes associated with the c-MET pathway [5], this pathway still holds future potential.

\section{TGF $\beta$ inhibitors}

In a preclinical trial, TGF $\beta$ tyrosine-kinase inhibitor (TKI) induced a tremendous mesenchymal-to-epithelial transition (MET) reversing EMT in CD44+ breast cancer cells, which justified its further development [39]. Initial results from studies of trabedersen, an antisense oligodeoxynucleotide directed against TGF $\beta 2$ mRNA, revealed promising efficacy in solid tumors known to overexpress TGF $\beta 2$ ligand [40].

\section{Immune modulatory/associated TNBC}

The "immunomodulatory" subtype is enriched in gene ontologies of the immune cell process including immune cell signaling (B, T, and NK cells), cytokine signaling, antigen processing-presentation, and core immune signal transduction pathways [5]. Compared with the other intrinsic groups defined by Sorlie et al. [3], claudin-low tumors expressed a high level of immune system response genes (B-cell, T-cell, and CD8-signatures) [2]. Additionally, Burstein et al., using an RNA-based gene profiling, identified a good prognostic subset called "Basal-like immune activated" (BLIA), overexpressing CTLA-4 on top of other genes overexpressed in immunomodulatory TNBC [4].

While different groups proposed slightly different analysis to define the group, it is clear that there are subset of TNBC that harbor a lot of modulatory signatures dictated by immune systems. The immune response signature was correlated with enhanced levels of immune cell infiltration and resulted in good clinical outcome in TNBC [2, 41-44]. Tumorinfiltrating lymphocytes seem predictive of neoadjuvant chemotherapy response $[45,46]$.

Immune-based therapies are actively developed in breast cancer (Table 1, Figure 4, and Supplementary Table 1). Whether specific immune system response gene amplification and/or immune pathway enrichment is predictive of treatment efficiency remains to be known. Due to lack of evidence so far, tumors with one of the characteristic were gathered in a common immune subgroup.

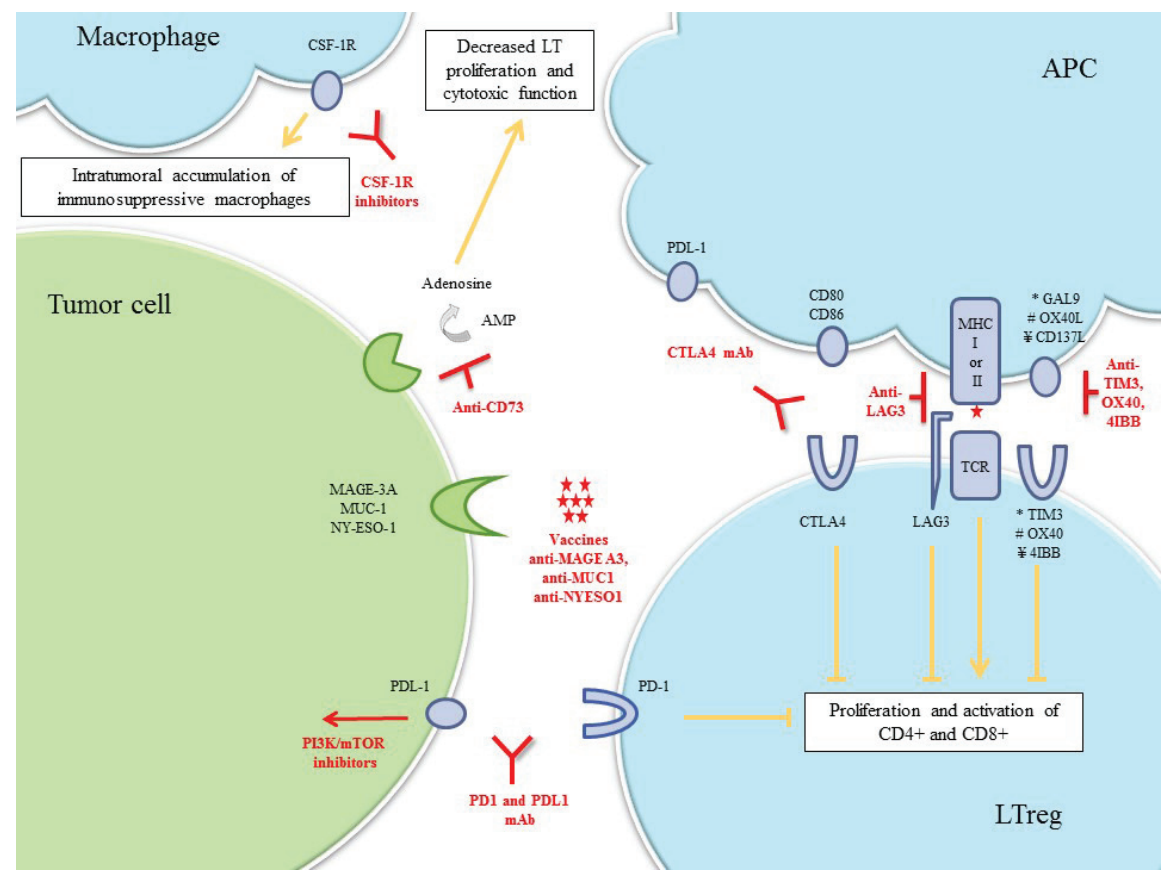

Figure 4: Immune-associated TNBC. Drug classes previously evaluated or currently being investigated in breast cancer clinical trials are shown.

Abbreviations: AMP, adenosine monophosphate; APC, antigen-presenting cell; CSF-1R, colony stimulating factor-1; CTLA-4, cytotoxicT-lymphocyte-antigen-4; LT lymphocyte T; LTreg, lymphocyte T regulator; mAb, monoclonal antibody; MAGE-A3, melanoma-associatedantige3; MHC, major histocompatibility complex; MUC1, mucin-1; PD-1, program-death-1; PDL-1, program-death-ligand-1; TCR, T-cell receptor. 


\section{Immune checkpoint blockade}

Immune checkpoint pathways are an elaborate series of cellular interactions that prevent the excessive activity of T-cells under normal conditions. In immune-associated TNBC, inhibiting these checkpoints and enhancing T-cell activity against tumor cells could be used therapeutically. Activation of cytotoxic-T-lymphocyte-antigen-4 (CTLA4), a cell surface receptor of lymphocyte $\mathrm{T}$ regulators, down-modulates the amplitude of T-cell activation. Two anti-CTLA-4- mAbs, ipilimumab and tremelimumab, are currently being evaluated in breast cancer, but no trial currently exists to assess their efficacy in the various stratifications of TNBC. Programmed-cell-death-1 (PD-1) and its ligand, PD-L1, are overexpressed in $20 \%$ of TNBCs [47]. The PD-L1/PD-1 pathway is a potent mechanism by which immunogenic tumors evade host immune response. Anti-PD-1 and anti-PD-L1-mAbs disrupt this ligandreceptor interaction, thereby enhancing T-cell immune response. PD-L1 expression appears to be a potential predictive biomarker of objective response rate (ORR) [48]. Inhibiting PTEN up-regulates PD-L1 expression, suggesting that agents targeting the PI3K pathway might be effective to enhance the antitumor adaptive immune response to TNBC [47]. The combination of cell signaling pathway inhibitors plus immune checkpoint blockade drugs needs to be explored in TNBC (Table 1 and Figure 4).

\section{Tumor vaccines}

Breast cancer vaccines targeting tumor antigens have been investigated for the past decade. Although no TNBC-specific antigen has been validated, several targets in breast cancer cells have been identified, including NYESO-1, MAGE-A3, and MUC-1 [49, 50]. NY-ESO-1 expression has been identified in $12-24 \%$ of TNBC patients, among whom $73 \%$ had high $\mathrm{Ab}$ response to NY-ESO-1, indicating high immunogenicity [51, 52]. Interestingly, immune gene signature was predictive of MAGE-A3 specific immunotherapeutic response [53].

\section{Luminal/apocrine TNBC}

LA-TNBC, despite lacking ERs and PRs, is enriched in hormonally regulated pathways. Indeed, AR overexpression can replace ER expression as a major component of steroid-related signaling $[5,10,54]$. This subgroup, which could include the LAR, the luminal A-B, the Burstein's LAR and molecular apocrine subtypes, shares other features including high luminal gene expression, lack of basal-cytokeratin markers, and low proliferation rate $[5,10,54]$. AR-positivity, defined as nuclear staining in at least $10 \%$ of cancer cells, has been detected in approximately one-third of TNBCs and is associated with good prognosis [55-57]. Interestingly, a low pCR rate of $6 \%-10 \%$ was observed in the luminal/ apocrine setting, after preoperative chemotherapy but there was trend for a better prognosis $[8,56]$.

\section{AR inhibitors}

Sensitivity to bicalutamide, an oral AR inhibitor, was better in LAR cell lines than in other subtypes and a recent phase II study confirmed the interest of such drug showing a $19 \%$ of clinical benefit rate at 24 weeks for ER/ PR-negative AR-positive breast cancer patients [5, 58]. Enzalutamide, a new generation anti-androgen, abrogated AR-mediated proliferation in vitro, and yielded $42 \%$ of clinical benefit rate at 16 weeks in advanced AR-positive TNBC $[59,60]$. Another compound, enobosarm, yielded a $35 \%$ clinical benefit in metastatic AR-positive breast cancer [61]. Recent data suggested that even non-LAR subtypes with relatively lower AR expression may also benefit from AR targeted therapy [62]. Various efforts to streamline the testing of AR in breast cancer and develop effective AR targeting treatment are currently made by researchers.

\section{Histone deacetylase (HDAC) inhibitors}

As $\mathrm{HDAC}$ regulates $\mathrm{AR}$ target genes in prostate cancer cells, HDAC-inhibitors were tested in TNBC and had low toxicity [63]. Furthermore, in-vivo data suggest that HDAC inhibitors cause cells with the TNBC phenotype to express ER and become sensitive to endocrine therapy [64]. Thus, clinical trials of HDACinhibitors and aromatase inhibitors in TNBC patients are underway (Table 1, Figure 5 and Supplementary Table 1).

\section{HER2-enriched TNBC}

Six to eight percent of TNBCs are considered to be HER2e [3]. In Lehmann's molecular classification of TNBC, HER2 did not appear as an independent classifier, but instead the majority of HER2e tumors segregated into LAR and BL2 subgroups [5, 10]. Indeed, HER2e-TNBC shared characteristics with LA-TNBC including PI3KCA mutations and high levels of luminal-like genes such as AR [54, 65]. Therefore, while we suggest this subgroup as a separate clinical entity, it is possible that LA-TNBC and HER2-enriched group can be grouped together in near future based on further scientific discoveries. Although the clinical role of minimal HER2 expression (HER2 $1+, 2+$ by IHC) in TNBC is largely unknown, there are opportunities to evaluate HER2-targeted therapies (Figure 5 and Supplementary Table 1).

\section{HER2-targeted therapy}

Central IHC analysis of breast cancer samples from the NSABP-B31 trial revealed that $10 \%$ of patients receiving adjuvant trastuzumab were actually HER2negative. In this population, trastuzumab had a clinical benefit ; however, the results of this subset analyses should be taken with extreme caution [66]. The phase III 


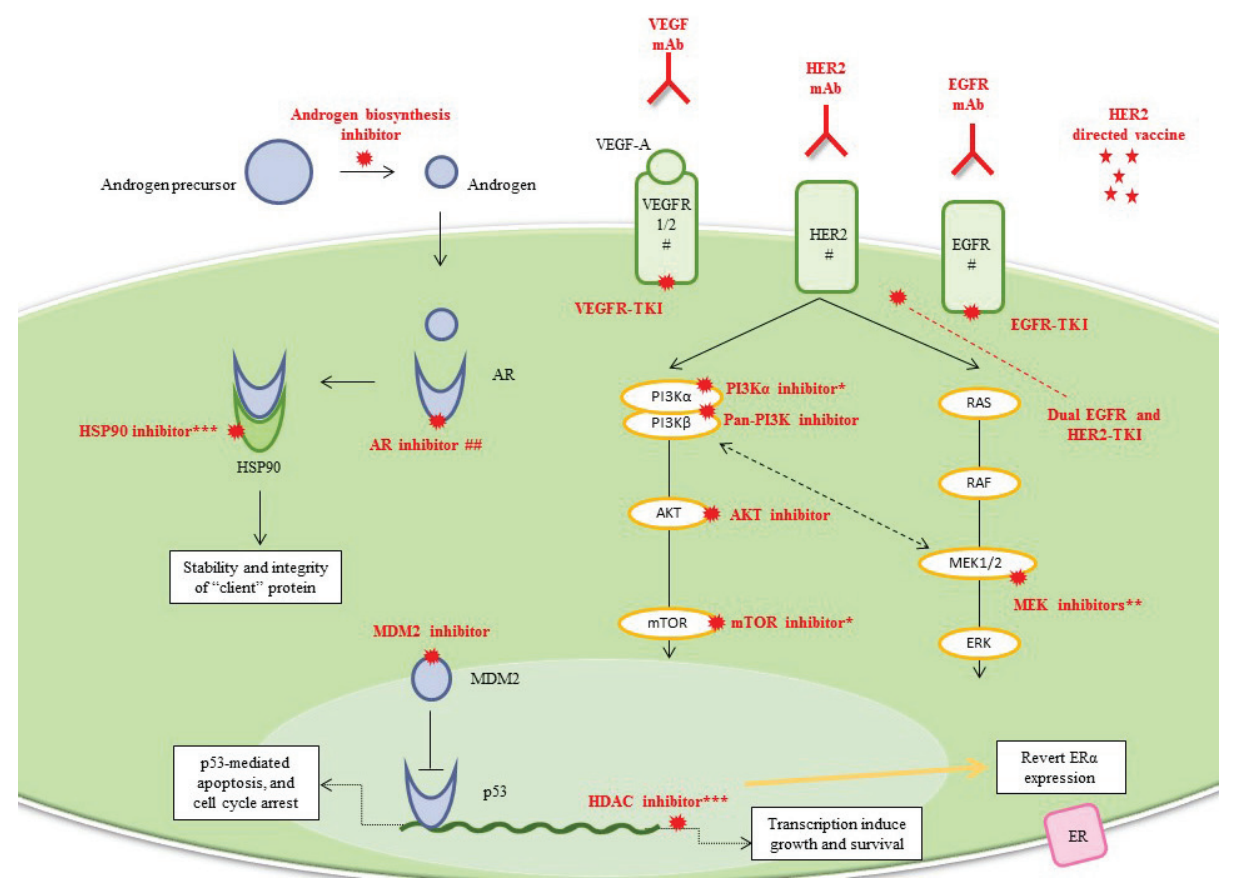

Figure 5: Luminal/apocrine TNBC and HER2-enriched TNBC. Drug classes previously evaluated or currently being investigated in breast cancer clinical trials are shown. ${ }^{*}$ Dual PI3K/AKT/mTOR inhibitors are on the way. **Current mechanistic-driven combination drugs use MEK inhibitors with: AR inhibitors, PI3K inhibitors, AKT inhibitors, and dual PI3K/mTOR inhibitors. ***Inhibition of HSP90, a molecular chaperone essential for the stability and integrity of various "client" proteins such as AR, is an attractive therapeutic target for cancer. \# Anti-HER2, anti-EGFR, and anti-VEGF treatments are more specific for HER2-enriched TNBC. \#\# AR signaling has an important role in the molecular apocrine subgroup, which mainly overlaps the luminal-TNBC subgroup but could also overlap the HER2eTNBC subgroup because of the high frequency of HER2 amplification.

Abbreviations: AR, androgen receptor; EGFR, epidermal growth factor receptor; HER2, human epidermal growth factor receptor 2; HDAC, histone deacetylase; HSP90, heat-shock protein 90; mAb, monoclonal antibody; MDM2, mouse double minute 2; TKI, tyrosinekinase inhibitor; VEGFA, vascular endothelial growth factor A; VEGFR, vascular endothelial growth factor receptor.

NASBP B47 trial should determine the clinical relevance of HER2-targeted therapy in HER2-low expression (IHC $1+$ or $2+)$ TNBC.

\section{HER2-directed vaccine}

Two recent phase II studies demonstrated a benefit of the HER2 peptide vaccine AE37, in patients with HER2-low expression, especially those with TNBC $(60 \%$ relative reduction in recurrence). Phase III in TNBC are warranted $[67,68]$.

\section{Overlapping pathways and potential therapeutics}

In our literature review, we noticed several signaling pathways that were common to multiple groups of TNBC. While this was not unexpected, it does suggest that investigations into therapeutics that inhibit these pathways should provide serious consideration to which subgroups of TNBC will be tested.

\section{EGFR targeted therapy}

EGFR is overexpressed primarily in ML-, BL-, and HER2e-TNBC [5, 10, 65]. EGFR and its downstream signaling pathways consequently appear as promising targets in these TNBC subsets [69]. In a xenograft model of ML-TNBC, treatment with an EGFR-TKI induced MET transition and subsequent tumor regression [28]. Various EGFR-TKIs given as monotherapy did not provide any clinical benefit in a cohort of unselected patients [69]. More concordant with preclinical results, EGFR mAbs combined with chemotherapy showed promising ORRs in TNBC patients [70, 71]. Complementary data showed minor inactivation of EGFR pathway in TNBC by EGFR inhibitors, potent testimony of activation of additional resistant pathways [72].

\section{Fibroblast growth factor receptor (FGFR) targeted therapy}

Because FGF2 ligand is highly express in BL[73], and FGFR is highly expressed in ML- and BRCAassociated tumors [5, 74], two kinds of FGFR inhibitors are being investigated in breast cancer: TKIs targeting both VEGFRs and FGFRs and pan-FGFR TKIs. In the first instance, results from a phase II trial of dovitinib in FGFR1-amplified breast cancer suggest that anti-FGFR therapy results in stable disease in TNBC [75]. In the second instance; since genomic alterations of FGFR are 
predictive of BCJ398 sensitivity [76], current clinical trials have restrictive inclusion criteria for biological markers (FGFR1 and/or FGFR2 amplification, or FGFR3 mutation) but are open to various solid cancers. This approach is necessary to obtain a sufficient number of patients and significant results.

\section{IGFR-targeted therapy}

IGFR-related signaling genes are heavily enriched in ML- and BL-TNBC. Excitingly, targeting this pathway in BL-TNBC may be highly effective as BRCA-deficient cells, unlike wild-type cells, cannot down-regulate IGFR expression [77]. However, neither BRCA status nor IGFR-1 plasma levels are biomarkers for anti-IGFR treatment. The biomarker issue raised for anti-IGFR therapy is common in oncology and also applies to studies investigating the VEGF pathway. Thus, phase III results in unselected patients have been disappointing [78].

\section{PI3K/AKT/mTOR pathway targeted therapy}

Up to $45 \%, 39 \%$, and $29 \%$ of "intrinsic" luminal-A, HER2e, and luminal-B, respectively, have PI3KCA mutations [65]. Preliminary data suggest that these mutations increase the sensitivity of cancer cells to PI3K/ AKT/mTOR inhibitors [79]. More controversial is the impact of PTEN loss as a predictor of treatment efficacy $[5,79]$. Phase I trials showed that class I pan-PI3K inhibitors elicited disease stabilization or partial response in TNBC [80]. At the same time, a beta-sparing PI3K inhibitor showed promising preliminary clinical activity in PI3KCA-mutant breast cancers [81]. Dual PI3K and mTOR inhibitor NVP-BEZ235 had a potent effect on ML- and LATNBC cell lines [5]. This sensitivity was confirmed in a phase I study [82]. In the future, laboratory marker analysis should be performed to determine the precise roles of PI3K mutation and PTEN loss and better select patients who would benefit from these targeted treatments.

\section{MAPK pathway targeted therapy}

MEK inhibitors appear to be a promising agents in ML-TNBC because the ERK1/2 pathway is overexpressed in this subtype [5]. If only $2 \%$ and $5 \%$ of all breast cancers have BRAF and KRAS mutations, respectively, a "RAS-like" transcriptional program confers sensitivity to MEK inhibitors in preclinical models of BL-TNBC [83]. In contrast, MEK inhibitors should not be relevant in LA-TNBC as PTEN loss is a negative predictor of MEK-inhibitors' efficiency [83]. An obvious feedback loop between the PI3K/AKT/mTOR and RAS/RAF/ $\mathrm{MEK} / \mathrm{ERK}$ pathways has direct clinical implications, as MEK inhibition leads to PI3K activation and vice versa [83]. Moreover, inhibition of MAPK activity restore ER expression and endocrine therapy response in vitro [84]. Even if single-agent MEK inhibitor may not be the most relevant treatment for TNBC, combination therapy using this drug may have clinical efficacy in TNBC.

\section{Angiogenesis inhibitors}

Three kinds of anti-angiogenic agents are currently on the market: anti-VEGF-A mAbs (e.g., bevacizumab), pan-VEGFR TKI (e.g., sunitinib, sorafenib, pazopanib), and VEGF-trap (e.g., aflibercept). The U.S. Food and Drug Administration's approval of bevacizumab for breast cancer was withdrawn because of insufficient benefit and consequent adverse effects in the global breast cancer population. In the adjuvant setting, adding bevacizumab to chemotherapy did not improve disease-free survival in unselected TNBC patients [85]. A meta-analysis of three phase III trials suggested that bevacizumab reduces the risk of progression of metastatic TNBC by 35\% [86]. Interestingly, claudin-low, basal, and HER2e display a VEGF-signature, sign of angiogenesis [87]. Concordant data suggest higher intratumoral expression of VEGFA in BL-TNBC and HER2e-TNBC, than in the MLTNBC $[88,89]$. There are no predictive biomarkers for angiogenesis inhibitors, yet. To obtain any relevant results and improve outcomes with the use of anti-angiogenic agents, we will need to preselect patients using predictive biomarkers.

\section{TP53 mutation targeting}

p53 mutations are detected in 100\%, 85\% and 40\% of HER2e-, basal and luminal TNBCs, respectively [10]. Targeting the p53 pathway can be both direct and indirect. E.g., MDM2 inhibitors could reactivate p53's tumor suppressor function in non-mutant tumors [90]. Defective P53-mediated cell-repair lead to G2-M dependency of cells, therefore offering a therapeutic strategy to target apoptosis in TNBC. Many apoptosis targeting agents are currently tested in solid tumor, and are recognized as upcoming drugs in TNBC.

\section{Therapeutic strategy and biomarker development}

There are numerous targets among subtypes as we reviewed here in TNBC; however their activity as single agents in TNBC has proven or might be limited. Further, there is limited number of actionable single gene mutation drivers in TNBC. Therefore, biologically driven combinatorial therapies should be considered. An extensive number of active clinical trials are investigating combinatory-targeted treatments on the basis of agents' synergistic effect in preclinical studies [91]. Specifically, these combination therapies should be considered in TNBC, based on the compensatory pathways activated by single pathway inhibition by targeted therapy or preclinical data suggesting their synergy: such as, EGFR- and MEKinhibitors; MEK-, MET- or PARP-inhibitors; VEGF- and mTOR inhibitors [92]. Further, because of the high rate of PI3K mutations in AR-positive tumors, PI3K- and AR-inhibitors should be pursued [93]. Although, multiple 
combination therapies are available to pursue as clinical trials, our incomplete knowledge of TNBC precludes our ability to provide a rationale for treatment prioritization.

Few clinical trials have assessed combination therapies in TNBC alone, and even fewer have assessed such therapy in the various TNBC subtypes (Table 1 and Supplementary Table 1). Thus, most trials are phase I studies involving various solid tumor types or unspecified breast cancer subtypes. Therefore, there is an urgent need to design clinical trials that assess drug efficacy in TNBC specifically, as this effect may be unobserved in studies involving a large unspecified population. We speculate that some drugs, such as EGFR-TKIs or VEGF-mAbs, may have already suffered from designs with incomplete annotation.

Additionally, a large proportion of preclinical studies utilize only a handful of established human cell lines that commonly do not represent all TNBC subtypes. For example, the TNBC cell line, MDA-MB-231, has been the workhorse of preclinical investigation for more than three decades and has provided much insight into the biology of primary tumor and metastases. However, MDA-MB-231 is a ML-TNBC cell line, and results derived from its study should be interpreted in the context of the ML-TNBC subgrouping. Preclinical studies assessing drug activity in TNBC should use multiple cell lines that encompass all molecular subtypes of the disease.

Another important element to consider is tumor evolution. Most tumor characterization is based on pretreatment core biopsies. However, tumor's genetic instability can cause changes in molecular characteristics at various times points of disease, as was demonstrated for PI3K pathway mutations [94]. So, despite the classification proposed, we do not know whether baseline classification will predict response after one treatment or even after weeks of natural tumor evolution. Furthermore, we do not know how these classifications will affect combination targeted therapy or combination treatments with conventional chemotherapy. Finally, we need to think about performing repeat core biopsies and developing less invasive measures of clinical assessment, such as monitoring circulating tumor cells and circulating free tumor DNA [95], to provide accurate and personalized treatment along the course of TNBC. Most clinical trials of targeted treatment enrolled heavily pretreated breast cancer patients without new characterization, but whether this is relevant is unknown. There is an urgent need to answer these questions to correctly design future studies.

Lastly, biomarkers for selecting patients for treatment are urgently needed [95]. A greater understanding of TNBC biology will uncover potential biomarkers that will facilitate clinical trials of novel treatments and the development of predictive biomarkers for these treatments. However, the main issue of how to identify biomarkers with high clinical validity and utility remains. PI3K mutation, VEGFR2/VEGF-A, BRCA1/2 mutations and 'BRCAness' have all been used to stratify patients in studies of anti-angiogenic agents or PARP inhibitor. With exception to BRCA1/2 mutations, no candidate biomarkers have been proven to have sufficient pragmatic validity in TNBC.

\section{CONCLUSIONS}

Developing personalized therapies for TNBC requires a comprehensive understanding of the molecular basis of its oncogenic pathways and microenvironmental changes, as well as the effects of the immune system and therapies on these pathways. The more we understand the biology, the more we are prompt to split TNBC disease into multiple subgroups. However, multiplication of subtypes could yield to "orphan" TNBC disease and unnecessary splitting with major issue to design powerful trial with sufficient number of patients. To overcome this issue, our review suggests five possible major clusters of TNBC based on current knowledge and clinical trial development. Each of them harbors a dominant biological function/pathway, which could justify the above distinction. Our review identified four predominant function/pathway: DNA-repair deficiency, EMT and CSC, immune-associated, androgen-receptor overexpression. Although, multiple papers explored TNBC gene expression profiling, our incomplete knowledge of TNBC biomarkers precludes our ability to provide clinically achievable TNBC grouping with rationale for targeted therapies. Thus, in this review, we detailed for each pathway, various molecular-based treatments which are currently being investigated.

Thus, the first clinical need is to develop robust biomarkers that reflect the molecular behavior of TNBC, to generate more homogenous TNBC subgroups. To discover targetable route, we should also think in term of activated pathways and not restrict our research to mutational or expression data [96].

The second is to determine whether these molecular targets are clinically relevant to the treatments. Currently, testing new drugs without any correlated biomarkers studies might be a waste of time. Current insight of BRCA1/2 mutation and AR expression level in management of TNBC illustrate well the discussion.

The third is to prevent resistance to the proposed treatment. Many cancer centers are attempting to create comprehensive treatment strategies for TNBC so that personalization of treatment can be initiated.

Based on our review, one approach could be first to select chemo-resistant population which can benefit from additional treatment using baseline molecular profiling and imaging during standard chemotherapy treatment [97, 98]. Secondly, patients could be selected based on their HR deficiency status and AR expression level. Remaining patients could be segregated into mesenchymal-TNBC or non-mesenchymal-TNBC to benefit from investigational treatments (Figure 6). Regardless of how you design 


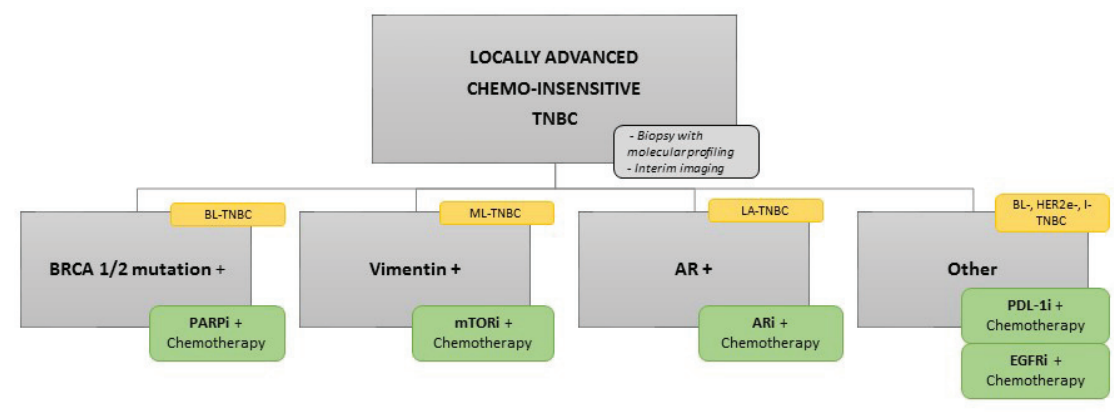

Figure 6: Flow chart of potent new TNBC clinical trial. Potent new design on TNBC clinical trial based on the classification we detailed and the new targeted drugs currently in development in TNBC.

Abbreviations: AR, androgen receptor; ARi, androgen receptor inhibitor; BL, basal-like; EGFR, epidermal growth factor receptor; EGFRi, epidermal growth factor receptor inhibitor; I, immunomodulary; LA, luminal/apocrine; ML, mesenchymal-like; mTORi, mTOR inhibitor; PDL-1i, PDL-1 inhibitor.

your personalized treatment in TNBC, multiple specimen correction is needed in the course of clinical trials or providing standard of care because we have yet to discover a robust treatment outcome predictable biomarkers. For sure, we see the future of personalized therapy development in TNBC as based on biology-oriented comprehensive approaches. However, we do not know yet if the biological classification based on gene expression profile or gene mutation/amplification can truly enrich the targets in TNBC.

\section{ACKNOWLEDGMENTS}

We thank the MD Anderson Moon Shot programs for their support. We also thank the Scientific Publications Department at MD Anderson (Tamara K. Locke) for manuscript editing.

\section{Contributors}

Conception and design: all authors; administrative support: Ana M. Gonzalez-Angulo, Naoto T. Ueno; collection and assembly of data: all authors; manuscript writing: all authors; table and figure preparation: Fanny Le Du, Bedrich L. Eckhardt; final approval of manuscript: all authors.

\section{FINANCIAL SUPPORT}

This research was supported by the generous philanthropic contributions to The University of Texas MD Anderson Moon Shots Program, the U.S. National Institutes of Health through MD Anderson's Cancer Center Support Grant (5 P30 CA016672-36) and by the Nellie B. Connally Breast Cancer Research Fund. It was also supported in part by a grant from the Eugène Marquis Cancer Center, Rennes, France (to F. Le Du).

\section{CONFLICTS OF INTEREST}

Novartis, Bristol Myers Squibb and BioMarine (Litton); EMD Serono Research \& Development Institute, Astellas Scientific and Medical Affairs (Ueno).

\section{Abbreviations}

$\mathrm{AR}$; androgen receptor, $\mathrm{BC}$; breast cancer, $\mathrm{CDK}$; cyclin-dependent kinase, CHT; chemotherapy, DFS; disease-free survival, DR; death receptor, EGFR; epidermal growth factor receptor, GSI; $\gamma$-secretase inhibitor; HDAC, histone deacetylase, IAP; inhibitor of apoptosis protein, mAb; monoclonal antibody, MUC1; mucin-1, ORR; objective response rate, OS; overall survival, pCR; pathological response rate, PFS; progression-free survival, $\mathrm{RR}$; response rate, $\mathrm{SMO}$; smoothened, SOC; standard of care, TKI; tyrosine-kinase inhibitor, VEGF; vascular endothelial growth factor receptor.

\section{REFERENCES}

1. Bauer KR, Brown M, Cress RD, Parise CA, Caggiano V. Descriptive analysis of estrogen receptor (ER)-negative, progesterone receptor (PR)-negative, and HER2-negative invasive breast cancer, the so-called triple-negative phenotype: a population-based study from the California cancer Registry. Cancer. 2007 May 1; 109:1721-8.

2. Prat A, Parker JS, Karginova O, Fan C, Livasy C, Herschkowitz JI, He X, Perou CM. Phenotypic and molecular characterization of the claudin-low intrinsic subtype of breast cancer. Breast Cancer Res. 2010 Sep 2; 12:R68.

3. Sørlie T, Perou CM, Tibshirani R, Aas T, Geisler S, Johnsen H, Hastie T, Eisen MB, van de Rijn M, Jeffrey SS, Thorsen T, Quist H, Matese JC, Brown PO, Botstein D, Lønning PE, Børresen-Dale AL. Gene expression patterns of breast carcinomas distinguish tumor subclasses with clinical implications. Proc Natl Acad Sci USA. 2001 Sep 11; 98:10869-74.

4. Burstein MD, Tsimelzon A, Poage GM, Covington KR, Contreras A, Fuqua S, Savage M, Osborne CK, Hilsenbeck SG, Chang JC, Mills GB, Lau CC, Brown PH. Comprehensive Genomic Analysis Identifies Novel Subtypes and Targets of Triple-negative Breast Cancer. Clin Cancer Res. 2014 Sep 10. 
5. Lehmann BD, Bauer JA, Chen X, Sanders ME, Chakravarthy AB, Shyr Y, Pietenpol JA. Identification of human triple-negative breast cancer subtypes and preclinical models for selection of targeted therapies. J Clin Invest. $2011 \mathrm{Jul} ; 121: 2750-67$.

6. Lehmann BD, Pietenpol JA. Identification and use of biomarkers in treatment strategies for triple-negative breast cancer subtypes. J Pathol. 2014 Jan 1; 232:142-50.

7. Mayer IA, Abramson VG, Lehmann BD, Pietenpol JA. New Strategies for Triple-Negative Breast CancerDeciphering the Heterogeneity. Clin Cancer Res. 2014 Feb 15; 20:782-90.

8. Masuda H, Baggerly KA, Wang Y, Zhang Y, GonzalezAngulo AM, Meric-Bernstam F, Valero V, Lehmann BD, Pietenpol JA, Hortobagyi GN, Symmans WF, Ueno NT. Differential Response to Neoadjuvant Chemotherapy Among 7 Triple-Negative Breast Cancer Molecular Subtypes. Clin Cancer Res. 2013 Oct 1; 19:5533-40.

9. Nielsen TO, Hsu FD, Jensen K, Cheang M, Karaca G, $\mathrm{Hu} \mathrm{Z}$, Hernandez-Boussard T, Livasy C, Cowan D, Dressler L, Akslen LA, Ragaz J, Gown AM, Gilks CB, van de Rijn M, Perou CM. Immunohistochemical and clinical characterization of the basal-like subtype of invasive breast carcinoma. Clin Cancer Res. 2004 Aug 15; 10:5367-74.

10. Prat A, Adamo B, Cheang MCU, Anders CK, Carey LA, Perou CM. Molecular characterization of basal-like and non-basal-like triple-negative breast cancer. Oncologist. 2013; 18:123-33.

11. Turner N, Tutt A, Ashworth A. Hallmarks of "BRCAness" in sporadic cancers. Nat Rev Cancer. 2004 Oct; 4:814-9.

12. Ossovskaya V, Wang Y, Budoff A, Xu Q, Lituev A, Potapova O, Vansant G, Monforte J, Daraselia N. Exploring molecular pathways of triple-negative breast cancer. Genes Cancer. 2011 Sep; 2:870-9.

13. Rouzier R, Perou CM, Symmans WF, Ibrahim N, Cristofanilli M, Anderson K, Hess KR, Stec J, Ayers M, Wagner P, Morandi P, Fan C, Rabiul I, Ross JS, Hortobagyi GN, Pusztai L. Breast cancer molecular subtypes respond differently to preoperative chemotherapy. Clin Cancer Res. 2005 Aug 15; 11:5678-85.

14. Silver DP, Richardson AL, Eklund AC, Wang ZC, Szallasi Z, Li Q, Juul N, Calogrias D, Buraimoh A, Fatima A, Gelman RS, Ryan PD, Tung NM, Nicolo AD, Ganesan S, Miron A, Colin C, Sgroi DC, Ellisen LW, Winer EP, Garber JE. Efficacy of Neoadjuvant Cisplatin in Triple-Negative Breast Cancer. J Clin Oncol. 2010 Mar 1; 28:1145-53.

15. Sikov WM, Berry DA, Perou CM, Singh B, Cirrincione C, Tolaney S, Kuzma CS. Impact of the addition of carboplatin (Cb) and/or bevacizumab (B) to neoadjuvant weekly paclitaxel (P) followed by dose-dense AC on pathologic complete response (pCR) rates in triple-negative breast cancer (TNBC): CALGB 40603 (Alliance). Cancer Res. 2014; in proceeding.

16. Von Minckwitz G, Schneeweiss A, Loibl S, Salat C, Denkert C, Rezai M, Blohmer JU, Jackisch C, Paepke S,
Gerber B, Zahm DM, Kümmel S, Eidtmann H, Klare P, Huober J, Costa S, Tesch H, Hanusch C, Hilfrich J, Khandan F, Fasching PA, Sinn BV, Engels K, Mehta K, Nekljudova V, Untch M. Neoadjuvant carboplatin in patients with triple-negative and HER2-positive early breast cancer (GeparSixto; GBG 66): a randomised phase 2 trial. Lancet Oncol. 2014 Jun; 15:747-56.

17. Minckwitz GV, Hahnen E, Fasching PA, Hauke J, Schneeweiss A, Salat C, Rezai M, Blohmer JU, Zahm DM, Jackisch C, Gerber B, Klare P, Kummel S, Eidtmann H, Paepke S, Nekljudova V, Loibl S, Untch M, Schmutzler RK, Groups G, A-BS. Pathological complete response (pCR) rates after carboplatin-containing neoadjuvant chemotherapy in patients with germline BRCA (gBRCA) mutation and triple-negative breast cancer (TNBC): Results from GeparSixto. J Clin Oncol. 2014; 32:5s.

18. Isakoff SJ, He L, Mayer EL, Goss PE, Traina TA, Carey LA, Krag K, Liu MC, Rugo HS, Stearns V, Come SE, Ryan PD, Finkelstein DM, Hartman A-R, Garber JE, Timms K, Winer EP, Ellisen LW. Identification of biomarkers to predict response to single-agent platinum chemotherapy in metastatic triple-negative breast cancer (mTNBC): Correlative studies from TBCRC009. J Clin Oncol. 2014; 32:5s.

19. Tutt A, Ellis P, Kilburn L, Gilett C, Pinder S, Abraham J, Barrett S, Barrett-Lee P, Chan S, Cheang M, Dowsett M, Fox L, Gazinska P. TNT: A randomized phase III trial of carboplatin (C) compared with docetaxel (D) for patients with metastatic or recurrent locally advanced triple negative or BRCA1/2 breast cancer (CRUK/07/012). SABCS. 2014; abstract S3-01.

20. McCabe N, Turner NC, Lord CJ, Kluzek K, Bialkowska A, Swift S, Giavara S, O'Connor MJ, Tutt AN, Zdzienicka MZ, Smith GCM, Ashworth A. Deficiency in the repair of DNA damage by homologous recombination and sensitivity to poly (ADP-ribose) polymerase inhibition. Cancer Res. 2006 Aug 15; 66:8109-15.

21. Fong PC, Boss DS, Yap TA, Tutt A, Wu P, MerguiRoelvink M, Mortimer $\mathrm{P}$, Swaisland $\mathrm{H}$, Lau A, O'Connor MJ, Ashworth A, Carmichael J, Kaye SB, Schellens JHM, de Bono JS. Inhibition of poly (ADPribose) polymerase in tumors from BRCA mutation carriers. N Engl J Med. 2009 Jul 9; 361:123-34.

22. Tutt A, Robson M, Garber JE, Domchek SM, Audeh MW, Weitzel JN, Friedlander M, Arun B, Loman N, Schmutzler RK, Wardley A, Mitchell G, Earl H, Wickens M, Carmichael J. Oral poly (ADP-ribose) polymerase inhibitor olaparib in patients with BRCA1 or BRCA2 mutations and advanced breast cancer: a proof-ofconcept trial. The Lancet. 2010 Jul; 376:235-44.

23. O'Shaughnessy J, Schwartzberg LS, Danso MA, Rugo HS, Miller K, Yardley DA, Carlson RW. A randomized phase III study of iniparib (BSI-201) in combination with gemcitabine/carboplatin $(\mathrm{G} / \mathrm{C})$ in metastatic triple-negative breast cancer (TNBC). J Clin Oncol. 2011; 29:abstr 1007. 
24. Mateo J, Ong M, Tan DSP, Gonzalez MA, de Bono JS. Appraising iniparib, the PARP inhibitor that never was-what must we learn? Nat Rev Clin Oncol. 2013 Oct $15 ; 10: 688-96$.

25. Shen Y, Rehman FL, Feng Y, Boshuizen J, Bajrami I, Elliott R, Wang B, Lord CJ, Post LE, Ashworth A. BMN 673, a Novel and Highly Potent PARP1/2 Inhibitor for the Treatment of Human Cancers with DNA Repair Deficiency. Clinical Cancer Research. 2013 Jul 23; 19:5003-15.

26. Rugo HS, Olopade O, DeMichele A, Van't Veer L, Buxton M, Hylton N, Yee D. Veliparib/carboplatin plus standard neoadjuvatn therapy for high risk breast cancer: First efficacy results from the I-SPY 2 TRIAL. Cancer Res. 2014; in proceeding.

27. Xia Q, Cai Y, Peng R, Wu G, Shi Y, Jiang W. The CDK1 inhibitor RO3306 improves the response of BRCAproficient breast cancer cells to PARP inhibition. Int J Oncol. 2014 Mar; 44:735-44.

28. Ueno NT. Targeting EGFR in Triple Negative Breast Cancer. Journal of Cancer. 2011; 2:324-8.

29. Thiery JP. Epithelial-mesenchymal transitions in tumour progression. Nat Rev Cancer. 2002 Jun; 2:442-54.

30. Neve RM, Chin K, Fridlyand J, Yeh J, Baehner FL, Fevr T, Clark L, Bayani N, Coppe J-P, Tong F, Speed T, Spellman PT, DeVries S, Lapuk A, Wang NJ, Kuo W-L, Stilwell JL, Pinkel D, Albertson DG, Waldman FM, McCormick F, Dickson RB, Johnson MD, Lippman M, Ethier S, Gazdar A, Gray JW. A collection of breast cancer cell lines for the study of functionally distinct cancer subtypes. Cancer Cell. 2006 Dec; 10:515-27.

31. Creighton CJ, Li X, Landis M, Dixon JM, Neumeister VM, Sjolund A, Rimm DL, Wong $\mathrm{H}$, Rodriguez A, Herschkowitz JI, Fan C, Zhang X, He X, Pavlick A, Gutierrez MC, Renshaw L, Larionov AA, Faratian D, Hilsenbeck SG, Perou CM, Lewis MT, Rosen JM, Chang JC. Residual breast cancers after conventional therapy display mesenchymal as well as tumor-initiating features. Proc Natl Acad Sci USA. 2009 Aug 18; 106:13820-5.

32. Khramtsov AI, Khramtsova GF, Tretiakova M, Huo D, Olopade OI, Goss KH. Wnt/beta-catenin pathway activation is enriched in basal-like breast cancers and predicts poor outcome. Am J Pathol. 2010 Jun; 176:2911-20.

33. Gupta PB, Onder TT, Jiang G, Tao K, Kuperwasser C, Weinberg RA, Lander ES. Identification of Selective Inhibitors of Cancer Stem Cells by High-Throughput Screening. Cell. 2009 Aug 21; 138:645-59.

34. Chang J, Landis M, Schott A, Pavlick A, Dobrolecki L, Korkaya H, Zhang X, Froehlich A, Rodriguez A, Rimawi M, Wicha M, Lewis M, Hayes D. Targeting Intrinsically-Resistant Breast Cancer Stem Cells with Gamma-Secretase Inhibitors. Cancer Research. 2010; Feb 10; 69:48-48.

35. Wang K, Zhang Q, Li D, Ching K, Zhang C, Zheng X, Ozeck M, Shi S, Li X, Wang H, Rejto P,
Christensen J, Olson P. PEST Domain Mutations in Notch Receptors Comprise an Oncogenic Driver Segment in Triple-Negative Breast Cancer Sensitive to a $\gamma$-Secretase Inhibitor. Clin Cancer Res. 2015 Mar 15; 21:1487-96.

36. Mueller KL, Madden JM, Zoratti GL, Kuperwasser C, List K, Boerner JL. Fibroblast-secreted hepatocyte growth factor mediates epidermal growth factor receptor tyrosine kinase inhibitor resistance in triple-negative breast cancers through paracrine activation of Met. Breast Cancer Res. 2012 Jul 12; 14:R104.

37. Zhang Y-W, Staal B, Essenburg C, Su Y, Kang L, West R, Kaufman D, Dekoning T, Eagleson B, Buchanan SG, Vande Woude GF. MET kinase inhibitor SGX523 synergizes with epidermal growth factor receptor inhibitor erlotinib in a hepatocyte growth factor-dependent fashion to suppress carcinoma growth. Cancer Res. 2010 Sep 1; 70:6880-90.

38. Daniel B, Campone M, Dieras V, Ervin T, Yu W, Paton V, Xia Q, Peterson A. OT3-01-11: A Randomized, Phase II Multicenter, Double-Blind, Placebo-Controlled Trial Evaluating MetMAb and/or Bevacizumab in Combination with Weekly Paclitaxel in Patients with Metastatic TripleNegative Breast Cancer. Cancer Research. 2011 Dec 15; 71:OT3-01-11-OT3-01-11.

39. Shipitsin M, Campbell LL, Argani P, Weremowicz S, Bloushtain-Qimron N, Yao J, Nikolskaya T, Serebryiskaya T, Beroukhim R, Hu M, Halushka MK, Sukumar S, Parker LM, Anderson KS, Harris LN, Garber JE, Richardson AL, Schnitt SJ, Nikolsky Y, Gelman RS, Polyak K. Molecular definition of breast tumor heterogeneity. Cancer Cell. 2007 Mar; 11:259-73.

40. Oettle H, Hilbig A, Seufferlein T, Luger T, Schmid RM, Von Wichert G, Schmaus S. Trabedersen (AP 12009) in the treatment of patients with advanced tumors: Completion of dose-escalation and first efficacy data. J Clin Oncol. 2010 28:abstr 2611.

41. Golicnik JP, Gazic B, Ovcaricek T, Matos E, Borstnar S. Prognostic value of routinely determined tumor infiltrating lymphocytes in triple-negative breast cancer. J Clin Oncol. 2014; 32:5s.

42. Finak G, Bertos N, Pepin F, Sadekova S, Souleimanova M, Zhao H, Chen H, Omeroglu G, Meterissian S, Omeroglu A, Hallett M, Park M. Stromal gene expression predicts clinical outcome in breast cancer. Nat Med. 2008 May; 14:518-27.

43. Desmedt C, Haibe-Kains B, Wirapati P, Buyse M, Larsimont D, Bontempi G, Delorenzi M, Piccart M, Sotiriou C. Biological Processes Associated with Breast Cancer Clinical Outcome Depend on the Molecular Subtypes. Clin Cancer Res. 2008 Aug 15; 14:5158-65.

44. Bianchini G, Qi Y, Alvarez RH, Iwamoto T, Coutant C, Ibrahim NK, Valero V, Cristofanilli $\mathrm{M}$, Green $\mathrm{MC}$, Radvanyi L, Hatzis C, Hortobagyi GN, Andre F, Gianni L, Symmans WF, Pusztai L. Molecular Anatomy of Breast Cancer Stroma and Its Prognostic Value in Estrogen 
Receptor-Positive and-Negative Cancers. J Clin Oncol. 2010 Oct 1; 28:4316-23.

45. Denkert C, Loibl S, Noske A, Roller M, Müller BM, Komor M, Budczies J, Darb-Esfahani S, Kronenwett R, Hanusch C, Törne C von, Weichert W, Engels K, Solbach C, Schrader I, Dietel M, Minckwitz G von. TumorAssociated Lymphocytes As an Independent Predictor of Response to Neoadjuvant Chemotherapy in Breast Cancer. J Clin Oncol. 2010 Jan 1; 28:105-13.

46. Denkert C, von Minckwitz G, Brase JC, Sinn BV, Gade S, Kronenwett R, Pfitzner BM, Salat C, Loi S, Schmitt WD, Schem C, Fisch K, Darb-Esfahani S, Mehta K, Sotiriou C, Wienert S, Klare P, André F, Klauschen F, Blohmer J-U, Krappmann K, Schmidt M, Tesch H, Kümmel S, Sinn P, Jackisch C, Dietel M, Reimer T, Untch M, Loibl S. Tumor-infiltrating lymphocytes and response to neoadjuvant chemotherapy with or without Carboplatin in human epidermal growth factor receptor 2-positive and triple-negative primary breast cancers. J Clin Oncol. 2015 Mar 20; 33:983-91.

47. Mittendorf EA, Philips AV, Meric-Bernstam F, Qiao N, Wu Y, Harrington S, Su X, Wang Y, Gonzalez-Angulo AM, Akcakanat A, Chawla A, Curran M, Hwu P, Sharma P, Litton JK, Molldrem JJ, Alatrash G. PD-L1 expression in triple-negative breast cancer. Cancer Immunol Res. 2014 Apr; 2:361-70.

48. Topalian SL, Hodi FS, Brahmer JR, Gettinger SN, Smith DC, McDermott DF, Powderly JD, Carvajal RD, Sosman JA, Atkins MB, Leming PD, Spigel DR, Antonia SJ, Horn L, Drake CG, Pardoll DM, Chen L, Sharfman WH, Anders RA, Taube JM, McMiller TL, Xu H, Korman AJ, Jure-Kunkel M, Agrawal S, McDonald D, Kollia GD, Gupta A, Wigginton JM, Sznol M. Safety, activity, and immune correlates of anti-PD-1 antibody in cancer. N Engl J Med. 2012 Jun 28; 366:2443-54.

49. Curigliano G, Viale G, Ghioni $M$, Jungbluth AA, Bagnardi V, Spagnoli GC, Neville AM, Nolè F, Rotmensz N, Goldhirsch A. Cancer-testis antigen expression in triple-negative breast cancer. Ann Oncol. 2011 Jan 1; 22:98-103.

50. Ju T, Cummings RD. A unique molecular chaperone Cosmc required for activity of the mammalian core 1 beta 3-galactosyltransferase. Proc Natl Acad Sci USA. 2002 Dec 24; 99:16613-8.

51. Ademuyiwa FO, Bshara W, Attwood K, Morrison C, Edge SB, Karpf AR, James SA, Ambrosone CB, O'Connor TL, Levine EG, Miliotto A, Ritter E, Ritter G, Gnjatic S, Odunsi K. NY-ESO-1 cancer testis antigen demonstrates high immunogenicity in triple negative breast cancer. PLoS ONE. 2012; 7:e38783.

52. Tessari A, Paolini B, Mariani L, Pilla L, Carcangiu ML, Moliterni A, Braud FGD, Cresta S. Expression of PD-L1 and NY-ESO-1 in early and advanced triple-negative breast cancer. J Clin Oncol. 2014; 32:5s.
53. Ulloa-Montoya F, Louahed J, Dizier B, Gruselle O, Spiessens B, Lehmann FF, Suciu S, Kruit WHJ, Eggermont AMM, Vansteenkiste J, Brichard VG. Predictive gene signature in MAGE-A3 antigen-specific cancer immunotherapy. J Clin Oncol. 2013 Jul 1; 31:2388-95.

54. Farmer $\mathrm{P}$, Bonnefoi $\mathrm{H}$, Becette $\mathrm{V}$, Tubiana-Hulin M, Fumoleau P, Larsimont D, MacGrogan G, Bergh J, Cameron D, Goldstein D, Duss S, Nicoulaz A-L, Brisken C, Fiche M, Delorenzi M, Iggo R. Identification of molecular apocrine breast tumours by microarray analysis. Oncogene. 2005 May 9; 24:4660-71.

55. Gonzalez-Angulo AM, Stemke-Hale K, Palla SL, Carey M, Agarwal R, Meric-Berstam F, Traina TA, Hudis C, Hortobagyi GN, Gerald WL, Mills GB, Hennessy BT. Androgen receptor levels and association with PIK3CA mutations and prognosis in breast cancer. Clin Cancer Res. 2009 Apr 1; 15:2472-8.

56. Park S, Koo J, Park HS, Kim J-H, Choi S-Y, Lee JH, Park B-W, Lee KS. Expression of androgen receptors in primary breast cancer. Annals of Oncology. 2009 Nov 3; 21:488-92.

57. McNamara KM, Yoda T, Takagi K, Miki Y, Suzuki T, Sasano H. Androgen receptor in triple negative breast cancer. J Steroid Biochem Mol Biol. 2013 Jan; 133:66-76.

58. Gucalp A, Tolaney S, Isakoff SJ, Ingle JN, Liu MC, Carey LA, Blackwell K, Rugo H, Nabell L, Forero A, Stearns V, Doane AS, Danso M, Moynahan ME, Momen LF, Gonzalez JM, Akhtar A, Giri DD, Patil S, Feigin KN, Hudis CA, Traina TA. Phase II Trial of Bicalutamide in Patients with Androgen Receptor-Positive, Estrogen Receptor-Negative Metastatic Breast Cancer. Clin Cancer Res. 2013 Oct 1; 19:5505-12.

59. Cochrane DR, Bernales S, Jacobsen BM, Cittelly DM, Howe EN, D'Amato NC, Spoelstra NS, Edgerton SM, Jean A, Guerrero J, Gómez F, Medicherla S, Alfaro IE, McCullagh E, Jedlicka P, Torkko KC, Thor AD, Elias AD, Protter AA, Richer JK. Role of the androgen receptor in breast cancer and preclinical analysis of enzalutamide. Breast Cancer Res. 2014; 16:R7.

60. Traina TA, O'Shaughnessy J, Nanda R, Schwartzberg L, Abramson VG, Cortes J, Peterson A, Tudor IC, Blaney M, Steinberg J, Kelly CM, Trudeau M, Awada A, Winer EP, Hudis C, Schmid P, Yardley DA. Stage 1 results from MDV3100-11: A 2-stage study of enzalutamide (ENZA), an androgen receptor (AR) inhibitor, in advanced AR+ triple-negative breast cancer (TNBC). SABCS. 2014; abstract P5-19-09.

61. Overmoyer B, Sanz-Altamira P, Taylor RP, Hancock ML, Dalton JT, Johnston MA, Steiner MS. Enobosarm: A targeted therapy for metastatic, androgen receptor positive, breast cancer. J Clin Oncol. 2014; 32:5s.

62. Barton VN, D'Amato NC, Gordon MA, Lind HT, Spoelstra NS, Babbs BL, Heinz RE, Elias A, Jedlicka P, 
Jacobsen BM, Richer JK. Multiple Molecular Subtypes of Triple-Negative Breast Cancer Critically Rely on Androgen Receptor and Respond to Enzalutamide In Vivo. Mol Cancer Ther. 2015 Feb 23.

63. Tate CR, Rhodes LV, Segar HC, Driver JL, Pounder FN, Burow ME, Collins-Burow BM. Targeting triple-negative breast cancer cells with the histone deacetylase inhibitor panobinostat. Breast Cancer Res. 2012; 14:R79.

64. Sabnis GJ, Goloubeva O, Chumsri S, Nguyen N, Sukumar S, Brodie AMH. Functional activation of the estrogen receptor- $\alpha$ and aromatase by the HDAC inhibitor entinostat sensitizes ER-negative tumors to letrozole. Cancer Res. 2011 Mar 1; 71:1893-903.

65. Cancer Genome Atlas Network . Comprehensive molecular portraits of human breast tumours. Nature. 2012 Oct 4; 490:61-70.

66. Paik S, Kim C, Wolmark N. HER2 status and benefit from adjuvant trastuzumab in breast cancer. N Engl J Med. 2008 Mar 27; 358:1409-11.

67. Mittendorf EA, Schneble EJ, Perez SA, Symanowski JT, Patil R, Vreeland TJ, Berry JS, Trappey AF, Clifton GT, Hofe E von, Ardavanis A, Ponniah S, Shumway NM, Papamichail M, Peoples GE. Primary analysis of the prospective, randomized, single-blinded phase II trial of AE37 vaccine versus GM-CSF alone administered in the adjuvant setting to high-risk breast cancer patients. J Clin Oncol. 2014; 32:5s.

68. Schneble EJ, Perez SA, Berry JS, Trappey AF, Vreeland T, Hale DF, Sears AK, Clifton GT, Hofe E von, Ardavanis A, Shumway NM, Ponniah S, Papamichail M, Peoples GE, Mittendorf EA. Comparison of recurrent and nonrecurrent breast cancer patients undergoing AE37 peptide vaccine therapy. J Clin Oncol. 2014; 32:5s.

69. Masuda H, Zhang D, Bartholomeusz C, Doihara H, Hortobagyi GN, Ueno NT. Role of epidermal growth factor receptor in breast cancer. Breast Cancer Res Treat. 2012 Nov; 136:331-45.

70. Baselga J, Gómez P, Greil R, Braga S, Climent MA, Wardley AM, Kaufman B, Stemmer SM, Pêgo A, Chan A, Goeminne J-C, Graas M-P, Kennedy MJ, Gil EMC, Schneeweiss A, Zubel A, Groos J, Melezínková H, Awada A. Randomized Phase II Study of the Anti-Epidermal Growth Factor Receptor Monoclonal Antibody Cetuximab With Cisplatin Versus Cisplatin Alone in Patients With Metastatic Triple-Negative Breast Cancer. J Clin Oncol. 2013 Jul 10; 31:2586-92.

71. Nabholtz J, Weber B, Mouret-Reynier M, Gligorov J, Coudert BP, Vanlemmens L, Petit T. Panitumumab in combination with FEC 100 (5-fluorouracil, epidoxorubicin, cyclophosphamide) followed by docetaxel (T) in patients with operable, triple-negative breast cancer (TNBC): Preliminary results of a multicenter neoadjuvant pilot phase II study. J Clin Oncol. 2011; 29:abstr 11574.
72. Carey LA, Rugo HS, Marcom PK, Mayer EL, Esteva FJ, Ma CX, Liu MC, Storniolo AM, Rimawi MF, ForeroTorres A, Wolff AC, Hobday TJ, Ivanova A, Chiu W-K, Ferraro M, Burrows E, Bernard PS, Hoadley KA, Perou CM, Winer EP. TBCRC 001: randomized phase II study of cetuximab in combination with carboplatin in stage IV triplenegative breast cancer. J Clin Oncol. 2012 Jul 20; 30:2615-23.

73. Sharpe R, Pearson A, Herrera-Abreu MT, Johnson D, Mackay A, Welti JC, Natrajan R, Reynolds AR, ReisFilho JS, Ashworth A, Turner NC. FGFR signaling promotes the growth of triple-negative and basal-like breast cancer cell lines both in vitro and in vivo. Clin Cancer Res. 2011 Aug 15; 17:5275-86.

74. Bane AL, Pinnaduwage D, Colby S, Bull SB, O’Malley FP, Andrulis IL. Expression profiling of familial breast cancers demonstrates higher expression of FGFR2 in BRCA2associated tumors. Breast Cancer Res Treat. 2009 Sep 1; 117:183-91.

75. André F, Bachelot T, Campone M, Dalenc F, PerezGarcia JM, Hurvitz SA, Turner N, Rugo H, Smith JW, Deudon S, Shi M, Zhang Y, Kay A, Porta DG, Yovine A, Baselga J. Targeting FGFR with Dovitinib (TKI258): Preclinical and Clinical Data in Breast Cancer. Clin Cancer Res. 2013 Jul 1; 19:3693-702.

76. Guagnano V, Kauffmann A, Wöhrle S, Stamm C, Ito M, Barys L, Pornon A. FGFR Genetic Alterations Predict for Sensitivity to NVP-BGJ398, a Selective Pan-FGFR Inhibitor. Cancer Discov. 2012; 2:1118-33.

77. Werner H, Bruchim I. IGF-1 and BRCA1 signalling pathways in familial cancer. The Lancet Oncology. 2012 Dec; 13:e537-e544.

78. Pollak M. The insulin and insulin-like growth factor receptor family in neoplasia: an update. Nat Rev Cancer. 2012 Mar; 12:159-69.

79. Sangai T, Akcakanat A, Chen H, Tarco E, Wu Y, Do K-A, Miller TW, Arteaga CL, Mills GB, Gonzalez-Angulo AM, Meric-Bernstam F. Biomarkers of response to Akt inhibitor MK-2206 in breast cancer. Clin Cancer Res. 2012 Oct 15; 18:5816-28.

80. Bendell JC, Rodon J, Burris HA, de Jonge M, Verweij J, Birle D, Demanse D, De Buck SS, Ru QC, Peters M, Goldbrunner M, Baselga J. Phase, I, dose-escalation study of BKM120, an oral pan-Class I PI3K inhibitor, in patients with advanced solid tumors. J Clin Oncol. 2012 Jan 20; 30:282-90.

81. Juric D, Infante J, Krop I, Kurkjian C, Patel M, Graham R, Wilson T. Evaluation of Tolerability and Anti-Tumor Activity of GDC-0032, a PI3K Inhibitor with Enhanced Activity Against PIK3CA Mutant Tumors, Administered to Patients with Advanced Solid Tumors. Eur J Cancer. 2013; 49:S168-168.

82. Burris H, Rodon J, Sharma S, Herbst RS, Tabernero J, Infante JR, Silva A. First-in-human phase I study of the oral 
PI3K inhibitor BEZ235 in patients (pts) with advanced solid tumors. J Clin Oncol. 2010; 28:abstr 3005.

83. Hoeflich KP, O'Brien C, Boyd Z, Cavet G, Guerrero S, Jung K, Januario T, Savage H, Punnoose E, Truong T, Zhou W, Berry L, Murray L, Amler L, Belvin M, Friedman LS, Lackner MR. In vivo Antitumor Activity of MEK and Phosphatidylinositol 3-Kinase Inhibitors in Basal-Like Breast Cancer Models. Clin Cancer Res. 2009 Jul 15; 15:4649-64.

84. Bayliss J, Hilger A, Vishnu P, Diehl K, El-Ashry D. Reversal of the estrogen receptor negative phenotype in breast cancer and restoration of antiestrogen response. Clin Cancer Res. 2007 Dec 1; 13:7029-36.

85. Cameron D, Brown J, Dent R, Jackisch C, Mackey J, Pivot X, Steger GG, Suter TM, Toi M, Parmar M, Laeufle R, Im Y-H, Romieu G, Harvey V, Lipatov O, Pienkowski T, Cottu P, Chan A, Im S-A, Hall PS, Bubuteishvili-Pacaud L, Henschel V, Deurloo RJ, Pallaud C, Bell R. Adjuvant bevacizumab-containing therapy in triple-negative breast cancer (BEATRICE): primary results of a randomised, phase 3 trial. The Lancet Oncology. 2013 Sep; 14:933-42.

86. O’Shaughnessy J, Romieu G, Diéras V, Byrtek M, Duenne AA, Miles D. Meta-Analysis of Patients with Triple-Negative Breast Cancer (TNBC) from Three Randomized Trials of First-Line Bevacizumab (BV) and Chemotherapy Treatment for Metastatic Breast Cancer (MBC). Cancer Res. 2010; 70:abstr P6-12-03.

87. Hu Z, Fan C, Livasy C, He X, Oh DS, Ewend MG, Carey LA, Subramanian S, West R, Ikpatt F, Olopade OI, van de Rijn M, Perou CM. A compact VEGF signature associated with distant metastases and poor outcomes. BMC Med. 2009; 7:9.

88. Bender RJ, Mac Gabhann F. Expression of VEGF and Semaphorin Genes Define Subgroups of Triple Negative Breast Cancer. PLoS, ONE. 2013 May 8; 8:e61788.

89. Glénisson M, Vacher S, Callens C, Susini A, CizeronClairac G, Le Scodan R, Meseure D, Lerebours F, Spyratos F, Lidereau R, Bièche I. Identification of new candidate therapeutic target genes in triple-negative breast cancer. Genes Cancer. 2012 Jan; 3:63-70.

90. Shangary S, Wang S. Small-Molecule Inhibitors of the MDM2-p53 Protein-Protein Interaction to Reactivate p53 Function: A Novel Approach for Cancer Therapy. Annu Rev Pharmacol Toxicol. 2009; 49:223-41.

91. Perez R, Schally AV, Popovics P, Cai R, Sha W, Rincon R, Rick FG. Antagonistic analogs of growth hormonereleasing hormone increase the efficacy of treatment of triple negative breast cancer in nude mice with doxorubicin; A preclinical study. Oncoscience. 2014; 1:665-73.

92. Zardavas D, Baselga J, Piccart M. Emerging targeted agents in metastatic breast cancer. Nat Rev Clin Oncol. 2013 Apr; 10:191-210.
93. Ibrahim YH, García-García C, Serra V, He L, TorresLockhart K, Prat A, Anton P, Cozar P, Guzmán M, Grueso J, Rodríguez O, Calvo MT, Aura C, Díez O, Rubio IT, Pérez J, Rodón J, Cortés J, Ellisen LW, Scaltriti M, Baselga J. PI3K inhibition impairs BRCA1/2 expression and sensitizes BRCA-proficient triple-negative breast cancer to PARP inhibition. Cancer Discov. 2012 Nov; 2:1036-47.

94. Gonzalez-Angulo AM, Ferrer-Lozano J, Stemke-Hale K, Sahin A, Liu S, Barrera JA, Burgues O, Lluch AM, Chen H, Hortobagyi GN, Mills GB, Meric-Bernstam F. PI3K Pathway Mutations and PTEN Levels in Primary and Metastatic Breast Cancer. Molecular Cancer Therapeutics. 2011 Apr 13; 10:1093-101.

95. Le Du F, Ueno NT, Gonzalez-Angulo AM. Breast Cancer Biomarkers: Utility in Clinical Practice. Current Breast Cancer Reports. 2013; 1-9.

96. Ocaña A, Montero JC, Pandiella A. Achilles' heel of triple negative cancer. Oncoscience. 2014; 1:763-4.

97. Hatzis C, Pusztai L, Valero V, Booser DJ, Esserman L, Lluch A, Vidaurre T, Holmes F, Souchon E, Wang H, Martin M, Cotrina J, Gomez H, Hubbard R, Chacón JI, Ferrer-Lozano J, Dyer R, Buxton M, Gong Y, Wu Y, Ibrahim N, Andreopoulou E, Ueno NT, Hunt K, Yang W, Nazario A, DeMichele A, O’Shaughnessy J, Hortobagyi GN, Symmans WF. A genomic predictor of response and survival following taxane-anthracycline chemotherapy for invasive breast cancer. JAMA. 2011 May 11; 305:1873-81.

98. Peintinger F, Kuerer HM, Anderson K, Boughey JC, Meric-Bernstam F, Singletary SE, Hunt KK, Whitman GJ, Stephens T, Buzdar AU, Green MC, Symmans WF. Accuracy of the combination of mammography and sonography in predicting tumor response in breast cancer patients after neoadjuvant chemotherapy. Ann Surg Oncol. 2006 Nov; 13:1443-9.

99. Dent RA, Lindeman GJ, Clemons M, Wildiers H, Chan A, McCarthy NJ, Singer CF, Lowe ES, Watkins CL, Carmichael J. Phase I trial of the oral PARP inhibitor olaparib in combination with paclitaxel for first- or secondline treatment of patients with metastatic triple-negative breast cancer. Breast Cancer Res. 2013; 15:R88.

100. Tolaney SM, Guo H, Barry WT, Larrabee K, Brock JE, Wagle N, Allen EMV, Paweletz C, Ivanova E, Janne PA, Overmoyer B, Wright JJ, Shapiro G, Winer EP, Krop IE. A phase II study of tivantinib (ARQ-197) for metastatic triple-negative breast cancer. J Clin Oncol. 2014; 32:5s.

101. Nanda R, Chow LQM, Dees C, Berger R, Gupta S, Geva R, Pusztai L, Dolled-Filhart M, Emancipator K, Gonzalez E, Houp J, Pathiraja K, Karantza V. A phase IB of pembrolizumab (MK-3475) in patients with 
advanced triple-negative breast cancer. SABCS. 2014; abstract S1-09.

102. Emens L, Braiteh F, Cassier P, DeLord J-P, Eder JP, Shen X, Xiao X, Wang Y, Hegde PS, Chen DS, Krop I. Inhibition of PD-L1 by MPDL3280A leads to clinical activity in patients with metastatic triple-negative breast cancer. SABCS. 2014; abstract PD1-6.
103. Curigliano G, Pivot X, Cortés J, Elias A, Cesari R, Khosravan R, Collier M, Huang X, Cataruozolo PE, Kern KA, Goldhirsch A. Randomized phase II study of sunitinib versus standard of care for patients with previously treated advanced triple-negative breast cancer. Breast. 2013 Oct; 22:650-6. 